\title{
Decapod crustaceans in fresh waters of southeastern Bahia, Brazil
}

\author{
Alexandre Oliveira de Almeida ${ }^{1,2}$, Petrônio Alves Coelho ${ }^{2}$, Joaldo Rocha Luz ${ }^{1}$, José Tiago \\ Almeida dos Santos $^{1}$ \& Neyva Ribeiro Ferraz ${ }^{1}$ \\ 1. Universidade Estadual de Santa Cruz, Departamento de Ciências Biológicas. Rodovia Ilhéus-Itabuna, km. 16. \\ 45662-000 Ilhéus, BA, Brazil; aalmeida@uesc.br \\ 2. Universidade Federal de Pernambuco, Departamento de Oceanografia, Programa de Pós-Graduação em Oceanografia. \\ Av. Arquitetura, s/n, Cidade Universitária. 50670-901 Recife, PE, Brazil.
}

Received 21-XI-2007. C Corrected 30-VI-2008. Accepted 31-VII-2008.

\begin{abstract}
A total of 117 species of freshwater decapod crustaceans are known from Brazil. Knowledge regarding the fauna of Decapoda from inland waters in the state of Bahia, northeast Brazil, is incipient. In spite of its wide territory and rich hydrographic net, only 13 species of limnetic decapods have been reported from that state. The objective of this contribution was to survey decapod crustaceans of some hydrographic basins in southeastern Bahia. The material described herein was obtained in samplings conducted between 1997 and 2005. Voucher specimens were deposited in the carcinological collections of the Museu de Zoologia, Universidade Estadual de Santa Cruz, Ilhéus, Brazil, and Departamento de Oceanografia, Universidade Federal de Pernambuco, Recife, Brazil. A total of 13 species was collected. The carideans were represented by the atyids Atya scabra (Leach, 1815 ) and Potimirim potimirim (Müller, 1881) and the palaemonids Macrobrachium acanthurus (Wiegmann, 1836), M. amazonicum (Heller, 1862), M. carcinus (Linnaeus, 1758), M. heterochirus (Wiegmann, 1836), M. jelskii (Miers, 1877), M. olfersi (Wiegmann, 1836), and Palaemon (Palaemon) pandaliformis (Stimpson, 1871). The brachyurans were represented by the portunids Callinectes bocourti A. Milne-Edwards, 1879 and $C$. sapidus Rathbun, 1895, the trichodactylid Trichodactylus fluviatilis Latreille, 1828 and the panopeid Panopeus rugosus A. Milne-Edwards, 1881. Macrobrachium heterochirus represents a new record from Bahia, and $M$. amazonicum is reported for the first time in southeast Bahia. The occurrence of two extreme different forms of T. fluviatilis was observed. Form A is characterized by the frontal margin of carapace bordered by conspicuous granules, the anterolateral margin provided with developed teeth plus granules, and the posterolateral margin provided with granulation similar to that found on the front. In form B the frontal margin is smooth or has an inconspicuous granulation; the anterolateral margin is usually provided with 1-3 notches, and teeth (1-2), if present, are small; and the posterolateral margin is smooth or slightly granulated. Rev. Biol. Trop. 56 (3): 12251254. Epub 2008 September 30.
\end{abstract}

Key words: fresh water shrimps, Caridea, Callinectes, Trichodactylus, Panopeus, Brachyura, Brazilian fauna.

Freshwater decapod crustaceans (e.g., shrimps, crayfishes, aeglid and brachyuran crabs) constitute a group of high ecological and economic importance (Magalhães 1999).

South American aquatic environments have been suffering progressive degradation, especially of the continental waters. This situation necessitates an acceleration of studies on the composition and biology of the aquatic communities (Bond-Buckup and Buckup 1994). Changes in freshwater habitats due to pollution, deforestation, silting, etc., can strongly affect the occurrence of crustaceans, especially those of very restricted geographic range, raising the threat of extinction of those species (Magalhães 1999). Recently, some freshwater species such as the shrimps Atya scabra (Leach, 1815) and Macrobrachium carcinus (Linnaeus, 1758) were included in the Brazilian Red List of threatened species as "vulnerable" in several Brazilian states (Amaral 2005). Accidental or intentional introduction of exotic species is 
another factor recognized, in most cases, to negatively affect the structure of aquatic communities (Rodríguez and Suárez 2001, Tavares and Mendonça Jr. 2004).

A total of 117 species of freshwater decapod crustaceans are known from Brazil (BondBuckup 2003, Buckup 2003, Magalhães 2003, Melo 2003). In the state of Bahia, northeast Brazil, in spite of its wide territory and rich hydrographic net, only 13 species of limnetic decapods have been reported to the present (Ramos-Porto and Coelho 1998, Magalhães 1998, Melo 2003). The previous contributions do not include estuarine species (e.g., some species of Callinectes Stimpson, 1860) that remain in fresh water for part of their life cycles.

Semper (1868) and Ortmann (1891) were the first authors to report a freshwater shrimp from Bahia (M. carcinus). A. Milne-Edwards (1869) described Trichodactylus crassus based on material from the state. In 1897, Hermann von Ihering and Arnold Ortmann published classic papers on shrimps from Brazil and South America, respectively, including some records from Bahia (Ihering 1897, Ortmann 1897). Moreira (1901), Rathbun (1906), Sawaya (1946), Holthuis (1952), Melo (1967), Bott (1969), and Gomes Corrêa (1977) also provided some species records of shrimps and brachyurans. Magalhães (1991), in his doctoral thesis, reported the occurrence of $T$. fluviatilis Latreille, 1828 for several localities in Bahia. Barros and Braun (1997) collected shrimps in a number of basins in the southern part of the state. However, the present-day diversity of freshwater decapods in the continental waters of Bahia is still far from well known.

In order to improve knowledge of the fauna of continental waters in Bahia, we report herein the results of a survey carried out in some hydrographic basins in the southeastern region of the state. We expect that the data presented here will be useful in further biological and ecological studies focusing on the fauna of the region, as well as representing a basis for conservation strategies.

\section{MATERIAL AND METHODS}

The study area is located between 13053'$15^{\circ} 17^{\prime} \mathrm{S}$, and $39^{\circ} 00^{\prime}-40^{\circ} 04^{\prime} \mathrm{W}$ (Fig. 1). The climate is warm and humid, without a dry season near the coast, where the rainfall is higher than 1,300 mm/year. Rainfall decreases with distance from the coast. The mean annual temperature is between 24 and $25^{\circ} \mathrm{C}$. Most of the area was originally covered by the Atlantic Forest, which extends from the coast to around $39^{\circ} 45^{\prime} \mathrm{W}$. The landscape is now mostly dominated by cocoa plantations, the main agricultural product of the region (Roeder 1975, Vinha et al. 1976, Argôlo 2004).

Most of the material examined was obtained during the project "Inventariamento da fauna de crustáceos decápodos do município de Ilhéus, Bahia", from May 2003 to February 2005. All collection sites visited during this period were geo-referenced. Sampling was carried out especially in the Cachoeira River, formed by the confluence of the Colônia and Salgado rivers, and in adjacent basins, such as Contas, Almada, Acuípe, Aliança, and other smaller basins. A small part of the material was collected in sporadic samplings in the Cachoeira River basin, between 1997 and 1999, by P. A. Coelho, and in 2001 and 2002, by A. O. Almeida and collaborators.

Specimens were collected with artisanal traps, locally called "manzuás", hand nets, or sieves. Voucher specimens were preserved in $70 \%$ ethanol and deposited in the carcinological collections of the Museu de Zoologia, Universidade Estadual de Santa Cruz (MZUESC), Ilhéus, Brazil, and the Departamento de Oceanografia, Universidade Federal de Pernambuco (DOUFPE), Recife, Brazil. Specimens of $T$. fluviatilis were compared to material deposited in the crustacean collections of the Museu de Zoologia, Universidade de São Paulo, Brazil (MZUSP), and the Universidade Santa Úrsula, Rio de Janeiro, Brazil (USU) (to be incorporated into the MZUSP collection, Dr. Marcos Tavares, pers. comm.). Most of the material deposited 


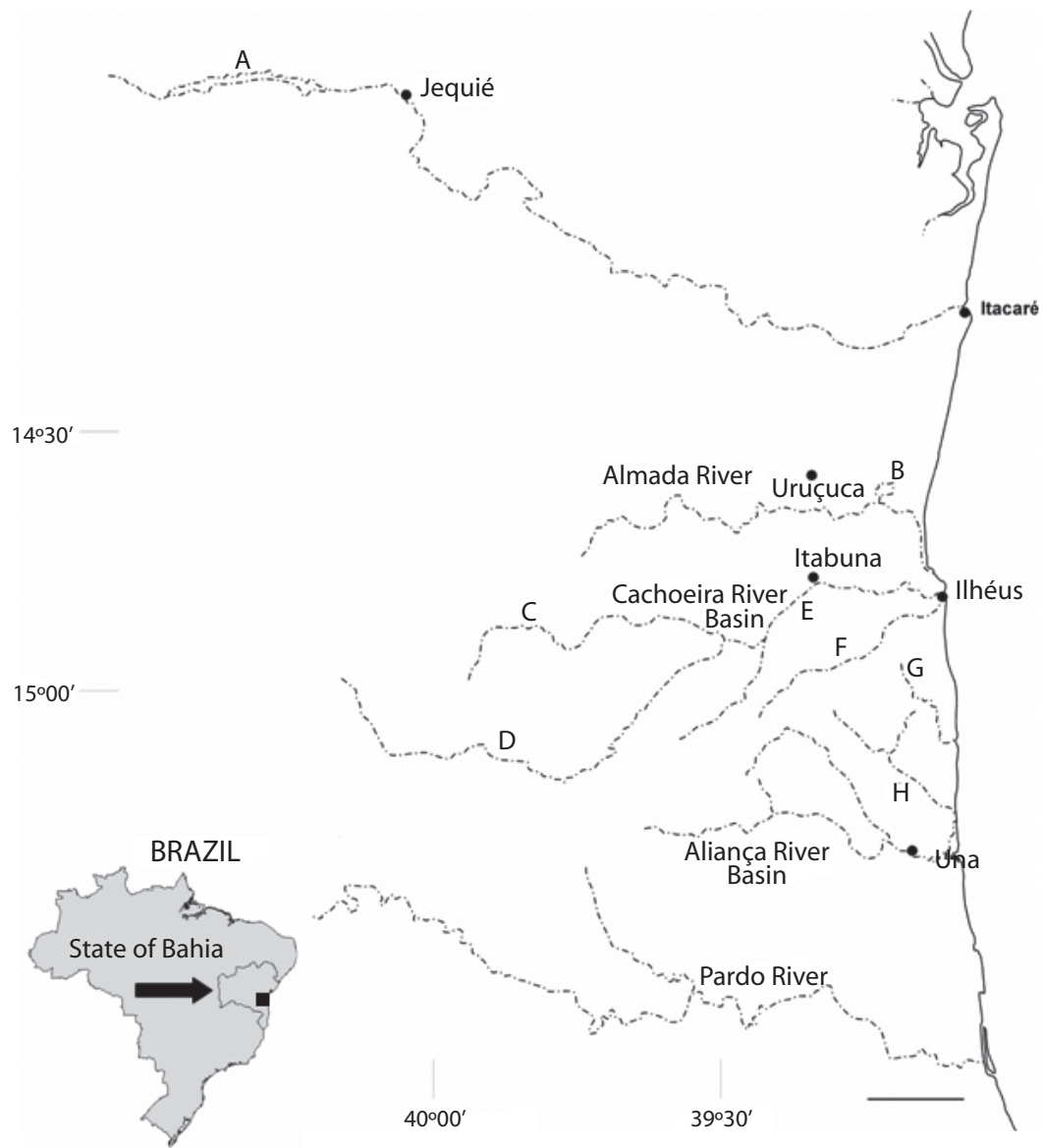

Fig. 1. Location of the study area, southeastern Bahia, Brazil. A. Reservatório da Pedra; B. Lagoa Encantada; C. Salgado River; D. Colônia River; E. Cachoeira River; F. Santana River; G. Acuípe River; H. Maruim River. Scale bar $=20$ km.

at MZUSP and USU was previously identified by Dr. Célio Magalhães (Instituto Nacional de Pesquisas da Amazônia), and later examined by the senior author. The measurements were taken with a vernier caliper to the nearest $0.1 \mathrm{~mm}$.

The classification adopted in this contribution follows Martin and Davis' (2001) proposed scheme to family level. In each family, the order of genera and species is alphabetical. Material examined, geographical range, ecological notes, taxonomic references for Brazil and for the state of Bahia (if any), are provided for each species. Distributional and taxonomic remarks are also included, as well as information on the economic importance and fisheries of some species. This information is a result of personal observations and conversations with fishermen in the Cachoeira and Contas river basins.

Other abbreviations used are: $\mathrm{m}=$ male, $\mathrm{f}$ $=$ female, juv $=$ juvenile, $n i=$ sex not identified, $\mathrm{CL}=$ carapace length, $\mathrm{CW}=$ carapace width. 


\section{RESULTS}

Infraorder Caridea Dana, 1852

Superfamily Atyoidea de Haan, 1849

Family Atyidae de Haan, 1849

Atya scabra (Leach, 1815)

References: Brazil - Oliveira (1945); Ramos-Porto and Coelho (1998); Bond-Buckup and Buckup (1999); Melo (2003); Rocha and Bueno (2004). State of Bahia - Barros and Braun (1997), Burunhém (sic) River (=Buranhém) near Eunápolis (39035'11'W, 16²4'49”S).

Material: 20m, 3f, 11.X.2002, Cachoeira River, Ilhéus (1447’31.6”S; 39¹1'07.8”W) (MZUESC\#110); 1m, 10.VII.2001, Cachoeira River, Ilhéus (1448'10.33”'S; 39¹0’03.65”W) (MZUESC\#113); 3m, 2f, 12.X.2002, Cachoeira River, Itapé (MZUESC\#115); 2m, 11.II.2001, Contas River, district of Taboquinhas, Itacaré (1420’'S; 39¹0’W) (MZUESC\#118); 3m, 1f, 1ni, 11.III.2004, small stream, Serra Grande, Uruçuca $\left(14^{\circ} 27^{\prime} \mathrm{S}\right.$; $\left.39^{\circ} 01^{\prime} \mathrm{W}\right)$ (MZUESC\#345); 3f, 27.II.2004, Cachoeira River, Ilhéus (1448'05.18'S; 3909'54.49”W) (MZUESC\#349); 16m, 14f, 31.III.2004, Santana River, Ilhéus (1451'16.8”S; 3905'58.6”W) (MZUESC\#357); 13m, 5f, 15.IV.2004, Santana River, Ilhéus (1451'16.8”'S; 3905'58.6” (MZ) (MZUES\#359); 3m, 30.IV.2004, Santana River, Povoado Rio do Engenho, Ilhéus (1451'07.4"S; 3904'12.8”W) (MZUESC\#365); 13m, 9f, 20.V.2004, Santana River, Fazenda Theobroma, Ilhéus (1450'58.2”S; 3904'52.7”W) (MZUESC\#444), 4ni, 08.VII.2004, Santana River, Ilhéus (1451'16.8”S; 3905'58.6”W) (MZUESC\#512); 5m, 5f, 03.II.2005, tributary of Tijuipinho River, Uruçuca (14²6'39.7'S; $39^{\circ} 03$ ' $13.2^{\prime} \mathrm{W}$ )

(MZUESC\#518); 3m, 8f, 03.II.2005, Tijuipinho River, Uruçuca (14²6’39.7”S; 3903'13.2”W) (MZUESC\#521); 11m, 7f, 03.II.2005, Tijuípe River, Uruçuca (14²3'53.5”'S; 3902'34.8”W) (MZUESC\#523); 2m, 30.VI.1999, Cachoeira River, Ilhéus (DOUFPE\#5386).

Distribution: America - Cuba, Jamaica, Puerto Rico, from Hispaniola Island to Curaçao and Trinidad, Mexico, Guatemala, Honduras, Nicaragua, Costa Rica, Panama, Colombia, Venezuela, and Brazil (Ceará, Pernambuco, Alagoas, Sergipe, Bahia, Espírito Santo, Rio de Janeiro, São Paulo, Santa Catarina, and Rio Grande do Sul). Africa - from Liberia to northern Angola, and from Cape Verde southward to Annobon (Hobbs and Hart 1982, Ramos-Porto and Coelho 1998, Melo 2003).

Ecological notes: In shallow rivers and streams, under stones and rocks or under vegetation along the bank (Melo 2003). According to Hobbs and Hart (1982) there is a general agreement that A. scabra frequents shallow waters, with records of no more than $1 \mathrm{~m}$, swiftly flowing water where a rocky substrate exists, although adult females and juveniles may frequent pools near the riffle areas. Young shrimps may also be found associated with submerged roots of plants along the bank. There are collection records ranging from sea level to $800 \mathrm{~m}$. In the Santana River, we observed an association between A. scabra and an aquatic phanerogam of the genus Mourera Aublet, 1775 (Podostemaceae), an abundant macrophyte in turbulent riffles of this river. The shrimp were easily collected among the coriaceous leaves of the plant, which possibly provide shelter for the animals.

Remarks: The occurrence of $A$. scabra is relatively well documented in Brazilian states between Ceará and Rio Grande do Sul, where it lives in rivers and streams that discharge into the Atlantic. However, its biology remains very poorly known. It was included in the Brazilian Red List of threatened species in a total of 10 Brazilian states as "vulnerable" (Amaral 2005).

Another species of Atya Leach, 1816 from Brazil, more rarely recorded, is A. gabonensis Giebel, 1875 which occurs in Piauí, Alagoas, Sergipe and São Paulo (Ramos-Porto and Coelho 1998, Melo 2003). This shrimp is recorded in basins north and south of Bahia, and the nonexistence of previous records is probably a result of the historical scarcity of collections in this part of Brazil. Atya scabra can be distinguished from $A$. gabonensis by the comparatively weakly sculptured carapace 
and by the flexor surface of the propodus of the third pereiopod with several cornified squamous tubercles organized in longitudinal rows, whereas in A. gabonensis, these tubercles are in general fewer, some forming rows. Moreover, A. gabonensis has conspicuous tufts of plumose setae on the flexor surface of the propodus of the third pereiopod (Hobbs and Hart 1982, Melo 2003).

Fishery: Relatively common in the region, where it is used as food and bait by riverine populations, at least in the Cachoeira, Santana, and Contas basins. Artisanal fishermen catch $A$. scabra by hand or with a kind of hand net locally called a "jereré", or with specially designed traps that are used in rocky bottoms in riffle areas. Because of its low commercial value, this species is not usually sold in markets, being mainly used for food or bait for M. carcinus fishing. However, interest in its capture is increasing, as a result of the overfishing of $M$. carcinus. In general, it is a species of local economic importance in Central America, the Caribbean, and northeast Brazil (see Holthuis 1980). Its common name in southeast Bahia is "curuca".

\section{Potimirim potimirim}

(Müller, 1881) (Fig. 2)

References: Brazil - Müller (1881) as Atyoida potimirim; Ihering (1897) as A. potimirim; Ortmann (1897) as A. potimirim; Moreira (1901) as A. potimirim; Sawaya (1946) as Ortmannia mexicana (Saussure, 1857); Ramos-Porto and Coelho (1998); Melo (2003); Rocha and Bueno (2004). State of Bahia Barros and Braun (1997), Burunhém (sic) River (=Buranhém) between Eunápolis and Porto Seguro, $8 \mathrm{~km}$ south of Vera Cruz $\left(16^{\circ} 25^{\prime} 28^{\prime \prime} \mathrm{S}\right.$, 39²1'W); Paim et al. (1997), Mucuri River, $\left(18^{\circ} \mathrm{S}, 40^{\circ} \mathrm{W}\right)$;

Material: 6m, 10f, 11.III.2004, smallstream, Serra Grande, Uruçuca $\left(14^{\circ} 27^{\prime} \mathrm{S}\right.$; 390. $\left.01^{\prime} \mathrm{W}\right)$ (MZUESC\#348); 2m, 14f; 03.II.2005, tributary of Tijuipinho River, Uruçuca (14²6'39.7'S; 3903'13.2”W) (MZUESC\#519).

Distribution: United States (Florida), Central America, and Brazil - Pernambuco,
Alagoas, Bahia, Rio de Janeiro, São Paulo, and Santa Catarina (Ramos-Porto and Coelho 1998, Melo 2003). Species introduced in Florida (Abele 1971).

Ecological notes: This species generally inhabits small, clearwater streams where it lives in gravel or sandy bottoms (Melo 2003). It also inhabits river edges, associated with bank vegetation or exogenous leaves accumulated on the streambed (Rocha and Bueno 2004). Our specimens were easily collected with a sieve and hand net in near-bank vegetation of small streams located in areas covered by Atlantic Forest vegetation.

Remarks: This small shrimp has been recorded in waters of the Atlantic slope in Central America and Brazil, from Pernambuco to Santa Catarina. The congeneric P. glabra (Kingsley, 1878) is known from the Antilles, Central America, and southeast Brazil to Santa Catarina (Ramos-Porto and Coelho 1998, Melo

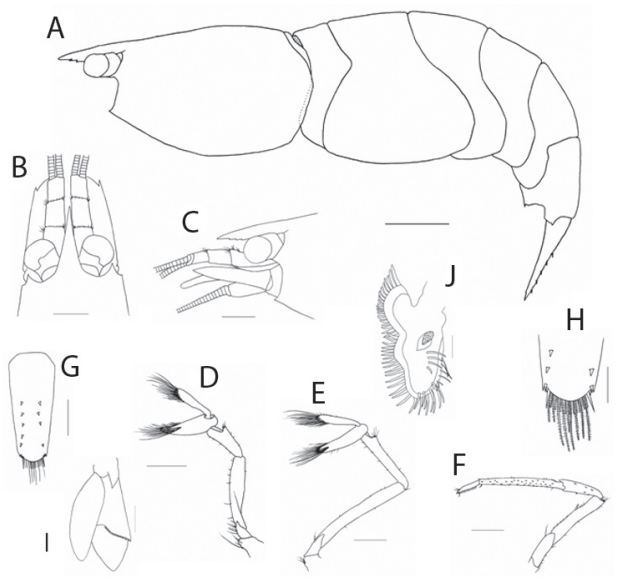

Fig. 2. Potimirim potimirim (Müller). A-I: ovigerous female from a tributary of the Tijuipinho River, Uruçuca, Bahia, Brazil (MZUESC\#519). A. lateral view; B. anterior region of carapace and frontal appendages, dorsal view; $\mathrm{C}$. same, lateral view; D. right pereiopod 1; E. right pereiopod 2; F. right pereiopod 3; G. telson, dorsal view; H. detail of the tip of the telson; I. right uropods, dorsal view. J. appendix masculina of the left pleopod 2, from a male of the lot MZUESC\#348, from Serra Grande, also from Uruçuca. Figures B, C, I - setae omitted. Scale bars: A = $2 \mathrm{~mm}$; B-G, $\mathrm{I}=1 \mathrm{~mm} ; \mathrm{H}=0.5 \mathrm{~mm} ; \mathrm{J}=0.25 \mathrm{~mm}$. 
2003). In the Pacific drainage it is documented from Mexico to Ecuador (Melo 2003).

A revision of the genus Potimirim Holthuis, 1954 is necessary in order to resolve certain taxonomic questions. Smalley (1963) examined a large series of $P$. glabra from Costa Rica, Nicaragua, and Panama, and proposed a synonymy between $P$. glabra and $P$. brasiliana Villalobos, 1959 the latter described by Villalobos (1959) from material collected in Rio de Janeiro. Chace and Hobbs (1969) and Holthuis (1986), analyzing material of $P$. glabra from Dominica, Trinidad, Martinique, and Colombia, accepted the proposed synonymy between these two species. Holthuis (1986) stated that whether this synonymy is justified will be revealed only when additional material is examined. Other workers have noted resemblances between $P$. potimirim and $P$. mexicana (Villalobos 1959, Abele 1971), which ranges over the Atlantic slope from Mexico to Costa Rica, and in the Antilles (Villalobos 1959, Rodríguez-Almaraz and Campos 1996). In general, studies in Brazil have recognized only two species, P. potimirim and P. glabra (Ramos-Porto and Coelho 1998, Melo 2003, Rocha and Bueno 2004). The possibility that P. glabra occurs in Bahia cannot be eliminated, because of the lack of collections in this state. In $P$. potimirim, the rostrum does not reach the first segment of the antennular peduncle, whereas in $P$. glabra, the rostrum exceeds the first segment of the antennular peduncle. Moreover, P. glabra has an U-shaped indentation between the first and second lobules of the appendix masculina, which is absent in $P$. potimirim (Melo 2003).

Superfamily Palaemonoidea Rafinesque, 1815

Family Palaemonidae Rafinesque, 1815 Macrobrachium acanthurus

(Wiegmann, 1836)

References: Brazil - White (1847) as Palaemon forceps H. Milne-Edwards, 1837; Ortmann (1897) as P. acanthurus; Ihering (1897) as $P$. acanthurus; Moreira (1901) as $P$. acanthurus; Sawaya (1946); Gomes Corrêa
(1977); Bond-Buckup and Buckup (1989); Ramos-Porto and Coelho (1990), Arraes and Ramos-Porto (1994); Ramos-Porto and Coelho (1998), Melo (2003), Rocha and Bueno (2004). State of Bahia - Ihering (1897) as P. acanthurus; Sawaya (1946); Holthuis (1952); Gomes Corrêa (1977), Itaparica and Ilhéus.

Material: 2f, 28-30.III.2001, Cachoeira River, Ilhéus (1448'05.18'S; 3909'54.49”'W) (MZUESC\#111); 2m, 11.II.2001, Contas River, district of Taboquinhas, Itacaré (14²0'S; $\left.39^{\circ} 10^{\prime} \mathrm{W}\right) \quad$ (MZUESC\#119); 3f, 21.V.2003, Parque Municipal da Boa Esperança, Ilhéus (1447'01.3"S; 39॰03'49.6”W) (MZUESC\#122); 2m, 9f, 1ni, 23.V.2003, Acuípe River, Ilhéus (1504'40”'S; 3901'40”'W) (MZUESC\#142); 3m, 2f, 11.III.2004, small stream, Serra Grande, Uruçuca (14²7'S; 3901' W) (MZUESC\#346); 7m, 2f, 01.IV.2004, Lagoa Encantada, Ilhéus (14³7'02.5”S; 3907'44.6”W) (MZUESC\#350); 2m, 1f, 31.III.2004, Santana River, Ilhéus (1451'17.7”S; 3906’04.1”W) (MZUESC\#353); 1m, 1f, 15.IV.2004, Santana River, Ilhéus (1451'16.8”'S; 39०05'58.6”W) (MZUESC\#360); 1f, 14.IV.2004, Lagoa Encantada, Ilhéus $\quad\left(14^{\circ} 37^{\prime} 20.8^{\prime \prime} \mathrm{S} ; \quad 39^{\circ} 08^{\prime} 32.5^{\prime \prime} \mathrm{W}\right)$ (MZUESC\#362); 2m, 1f, 30.IV.2004, Santana River, Ilhéus (1451'17.7”S; 3906'04.1”W) (MZUESC\#364); 10m, 9f， 30.IV.2004, Santana River, Povoado Rio do Engenho, Ilhéus (1451'07.4”S; 3904'12.8”W) (MZUESC\#366); 3m, 06.IV.2004, Acuípe

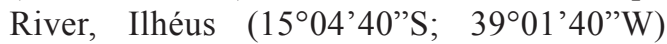
(MZUESC\#375); 2m, 1f, 06.IV.2004, channel at Siriíba Beach, district of Olivença, Ilhéus (1457’33”S; 3900'22”W) (MZUESC\#377); 1m, 30.IV.2004, Santana River, Povoado Rio do Engenho, Ilhéus (1451'07.4”S; 3904'12.8”W) (MZUESC\#443); 1m, 2f, 20.V.2004, Santana River, Fazenda Theobroma, Ilhéus (1450'58.2”'S; 3904'52.7”W) (MZUESC\#446); 7f, 13.V.2004, Santana River, Ilhéus (1451'16.8”S; 3905'58.6”W) (MZUESC\#447); 2m, 17.IX.2004, Santana River, Ilhéus (1451'16.8”S; 3905'58.6”W) (MZUESC\#450); 1f, 02.II.2005, small 
stream, Estação Experimental da CEPLAC, Una (15 $\left.15^{\circ} 02.3 ” S ; \quad 39^{\circ} 05^{\prime} 21.5^{\prime \prime} \mathrm{W}\right)$ (MZUESC\#515); 1m, 02.II.2005, Maruim River, Una (15'11'52.7'S; 3901'54.8”W) (MZUESC\#516); 3m, 2f, 22.II.2005, Almada River, Ilhéus (1440'01.2”S; 3904'26.5”W) (MZUESC\#524), 5m, 2f, 22.II.2005, Almada River, Ilhéus (14³9'46.7'S; 3904'53.2”W) (MZUESC\#525); 4m, 22.II.2005, Almada River, Ilhéus (14³9'09.6”S; 3904'58.7’W) (MZUESC\#526); 1f， 22.II.2005, Almada River, Ilhéus (1445'07.5”S; 3903'51.2”W) (MZUESC\#560).

Distribution: North Carolina, Georgia, Florida, Mississippi, Louisiana, Texas, Mexico, Cuba, Haiti, Dominican Republic, Puerto Rico, Nicaragua, Panama, Colombia, Venezuela, Surinam, and Brazil (from Pará to Rio Grande do Sul) (Ramos-Porto and Coelho 1998, Melo 2003).

Ecological notes: Freshwater species which requires an estuarine period in its life cycle (Holthuis 1952). In turbid, generally slow waters, with abundant marginal vegetation and muddy substratum (Gamba 1982, Melo 2003). Gamba (1982), studying the shrimp fauna in several rivers in Venezuela, found M. acanthurus at altitudes no higher than $20 \mathrm{~m}$ above sea level, and no more than $30 \mathrm{~km}$ from the river mouth. On the other hand, Rodríguez-Almaraz and Campos (1996) reported M. acanthurus $360 \mathrm{~km}$ upstream in Nuevo León, Mexico. Yet Gamba (1982) observed post-larvae, juveniles, and adults very close to the sea, in rivers with transparent waters and stony stream beds. In rivers with turbid waters and muddy beds, she found juveniles up to $11 \mathrm{~km}$ from the mouth.

Remarks: This is a large-sized shrimp species, widely distributed from North Carolina to southern Brazil, in rivers of the Atlantic drainage, and also in the Antilles.

The first report on the occurrence of $M$. acanthurus in Bahia was provided by Ihering (1897); the species was further mentioned for this state by Sawaya (1946) and Holthuis (1952). However, no locality information was provided in these papers. Although this shrimp is very common in Bahia, it has been rarely recorded.
Mature males of this species can be easily recognized by the propodus and dactyli subequal in length to the palm, covered by a dense velvety pubescence. Other typical characters are: merus, carpus, and palm with spines; rostrum almost straight and armed with 9 to 11 regularly distributed dorsal teeth, 2 behind the orbit, and 4 to 7 ventral teeth (Holthuis 1952, Bond-Buckup and Buckup 1989).

Fishery: The economic importance of $M$. acanthurus in Bahia was first mentioned by Ihering (1897). He said, in litt. "No mercado da Bahia vende-se como estimada comida Pal. acanthurus". In fact, this shrimp is the second most important species in economic importance in the Cachoeira and Contas basins. It is sold in markets and also used as food by riverine populations. It is also sold in smoke-dried form along the roads of the region. Interest in $M$. acanthurus capture is increasing because of the decline of $M$. carcinus populations in the region. Fishermen capture M. acanthurus with an artisanal trap called "manzuá". Its common name in southeast Bahia is "calambau". In other countries this shrimp seems to be of secondary economic importance (Holthuis 1980).

\section{Macrobrachium amazonicum (Heller, 1862) (Fig. 3)}

References: Brazil - White (1847) as Palaemon Lamarrei White, 1847; Smith (1869) as P. ensiculus Smith, 1869; Ortmann (1897) as P. amazonicus; Moreira (1901) as P. amazonicus; Holthuis (1952); Gomes Corrêa (1977); Kensley and Walker (1982); Ramos-Porto and Coelho (1990); Arraes and Ramos-Porto (1994); Ramos-Porto and Coelho (1998); Melo (2003); Magalhães et al. (2005). State of Bahia - Dra. Angélica M.A. Corrêa (pers. comm.), Açude Rômulo Campos, Itapicuru River basin, Itiúba.

Material: 17m, 29f, 06.VII.2001, Contas River, Reservatório da Pedra, Jequié (135's; $\left.40^{\circ} 03^{\prime} \mathrm{W}\right)$ (MZUESC\#332).

Distribution: Venezuela, Guyana, Surinam, French Guyana, Brazil (Amapá, Pará, Maranhão, Piauí, Ceará, Rio Grande 


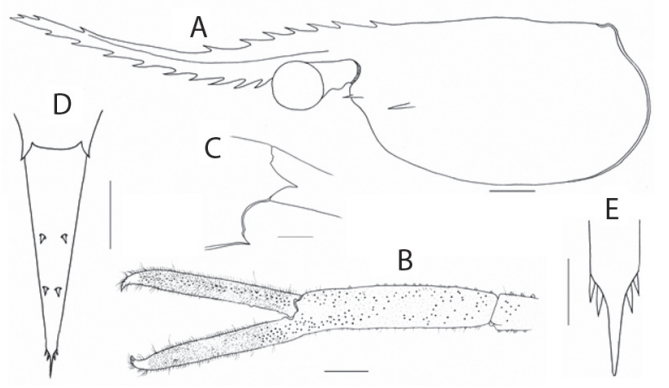

Fig. 3. Macrobrachium amazonicum (Heller) from the Reservatório da Pedra, Contas River, Bahia, Brazil, male (MZUESC\#332). A. carapace, lateral view; B. right pereiopod 2; C. pleonite 6 and telson, lateral view; D. telson, dorsal view; E. detail of the tip of the telson. Scale bars: A, $\mathrm{B}, \mathrm{D}=2 \mathrm{~mm} ; \mathrm{C}=1 \mathrm{~mm} ; \mathrm{E}=0.5 \mathrm{~mm}$.

do Norte, Paraíba, Pernambuco, Amazonas, Acre, Mato Grosso, Goiás, Mato Grosso do Sul, São Paulo, and Paraná), Ecuador, Peru, Bolivia, Paraguay, and Argentina (Melo 2003, Magalhães et al. 2005).

Ecological notes: In the Pantanal, found in rivers, baías (freshwater ponds and lakes), backwaters, and swamps, sandy and silty beaches, aquatic vegetation including floating macrophytes, and shoreline vegetation (Magalhães 2000). Reported from 0 to $800 \mathrm{~m}$ above sea level, on sandy and rocky bottoms, in limpid to turbid waters (Arraes and RamosPorto 1994).

Remarks: $M$. amazonicum has as native distribution the coastal river basins of northern South America, from Venezuela to northern Brazil, as well as in most of the Orinoco, Amazon, Paraguay, and lower Paraná river basins (Magalhães et al. 2005). It is also found in several rivers and reservoirs in the northeastern states of Brazil (Ramos-Porto and Coelho 1990, Arraes and Ramos-Porto 1994, Ramos-Porto and Coelho 1998), where it was introduced by the Departamento Nacional de Obras Contra a Seca (DNOCS) for aquaculture purposes (Coelho 1963). Magalhães et al. (2005) hypothesized that $M$. amazonicum is not native to the Upper Paraná River basin, but was deliberately or accidentally introduced there.
Macrobrachium amazonicum is known from northern Bahia, a semi-arid region, in Açude Rômulo Campos, Vale do Jacurici, Itapicuru basin, municipality of Itiúba, where it was introduced as forage for fish in the 1960s by DNOCS (Dr. Angélica M.A. Corrêa, pers. comm.). The present record is the first from the Contas River basin, one of the five most important rivers in Bahia. The Contas River is about $476 \mathrm{~km}$ long, three-fourths of which is located in the semi-arid interior of the state. The collection site, Reservatório da Pedra, is one of the made-man reservoirs along the Contas River (municipality of Jequié) (Rocha Filho 1976). No other data on species distribution and ecology and on the possible route of introduction of this species into this basin are available to us.

Adults of $M$. amazonicum can be recognized by the long slender rostrum, which reaches distinctly beyond the scaphocerite, the anterior tip directed upwards. The dorsal margin bears 9 to 12 teeth, the first of them located on the carapace just behind the orbit. The ventral margin bears 8 to 10 teeth. The telson gradually tapers towards the posterior margin, ending in a sharp median point. Two pairs of spines are located on the posterior margin of the telson; the inner pair do not overreach the tip of it. The tip of the telson in older specimens reaches farther beyond the inner pair of spines than in younger specimens (Holthuis 1952). However, these characteristics are not marked in immature individuals. At this stage, juvenile forms could be confused with two species of similar morphology, M. jelskii (Miers, 1877 ) and $M$. acanthurus (García-Dávila and Magalhães, 2003; Magalhães et al. 2005). See Holthuis (1952) and García-Dávila and Magalhães (2003) for more information on differential characteristics between M. amazonicum and M. jelskii.

Fishery: No information on regional utilization of M. amazonicum as food is available to us. In the Açude Rômulo Campos in northern Bahia, as well as in many of the reservoirs in semi-arid northeastern Brazil, it is caught for commerce and subsistence (Dra. Angélica M.A. Corrêa, pers. comm.). In the state of Pará, 
northern Brazil, this shrimp is well accepted in the market and is widely exploited by the artisanal fishery. Experimental cultivation has been practiced since the mid-1990s (MoraesRiodades et al. 1999). Experimental rearing in earthen ponds and cages is also conducted by two institutions in the state of São Paulo (Magalhães et al. 2005).

\section{Macrobrachium carcinus (Linnaeus, 1758)}

References: Brazil - White (1847) as Palaemon Jamaicensis (Herbst, 1792); Smith (1869) as P. Jamaicensis; Ihering (1897) as $P$. jamaicensis; Ortmann (1897) as P. jamaicensis; Moreira (1901) as P. jamaicensis; Sawaya (1946) as Macrobrachium jamaicense; Holthuis (1952); Gomes Corrêa (1977); Bond-Buckup and Buckup (1989); Ramos-Porto and Coelho (1990, 1998); Melo (2003); Rocha and Bueno (2004). State of Bahia-Semper (1868) as P. jamaicensis; Ortmann $(1891,1897)$ as P. jamaicensis, Caravelas; Gomes Corrêa (1977), Ilhéus.

Material: 1f, 28-30.III.2001, Cachoeira River, Ilhéus (1448'05.18'S; 3909'54.49”'W) (MZUESC\#109); 1m, 3f, 11.II.2003, Contas River, district of Taboquinhas, Itacaré (14 $20^{\circ} \mathrm{S}$; 39¹0'W) (MZUESC\#120); 1f, 11.III.2004, small stream, Serra Grande, Uruçuca $\left(14^{\circ} 27^{\prime} \mathrm{S}\right.$; 3901'W) (MZUESC\#344); 1f，30.IV.2004, Santana River, Povoado Rio do Engenho, Ilhéus (1451'07.4”S; 3904'12.8”W) (MZUESC\#368); 1f，08.VII.2004，Santana River, Ilhéus, (1451'16.8”S; 3905'58.6”W) (MZUESC\#448), 3m, 17.IX.2004, Santana River, Ilhéus (1451'16.8”S; 3905'58.6”W) (MZUESC\#449).

Distribution: United States (Florida, Mississippi, Texas), Mexico, Guatemala, Nicaragua, Costa Rica, Panama, Cuba, Puerto Rico, Jamaica, Barbados, Lesser Antilles, Colombia, Venezuela, Guyana, Surinam, and Brazil (Pará, Piauí, Ceará, Pernambuco, Alagoas, Sergipe, Bahia, Espírito Santo, Rio de Janeiro, São Paulo, Santa Catarina, and Rio Grande do Sul) (Ramos-Porto and Coelho 1998, Melo 2003).
Ecological notes: In fresh and brackish waters (Ramos-Porto and Coelho 1998, Melo 2003). Adults prefer to hide among rocks in riffles. In Venezuelan rivers, Gamba (1982) found juveniles of $M$. carcinus from 6 to 35 $\mathrm{km}$ from the river mouth, while the adults were captured at altitudes as high as $140 \mathrm{~m}$.

Remarks: $M$. carcinus is the largest freshwater shrimp occurring in Brazil. It has been widely recorded from Florida to southern Brazil, including the Antilles (Ramos-Porto and Coelho 1998, Melo 2003), in rivers of the Atlantic drainage.

The first report on the occurrence of $M$. carcinus of Bahia was provided by Semper (1968), who made no mention of the site of collection. Ortmann (1897) and Gomes Corrêa (1977) reported this shrimp from southern and southeastern Bahia, respectively. So, although common, this species has been rarely recorded from the state.

This species can be easily distinguished from the other Macrobrachium Bate, 1868 species in Brazil in having the carpus of the second pereiopod distinctly shorter than the merus. The second pereiopods are very strong and heavier than the other legs. They are spined, equal in size and shape. The fingers are slender, slightly shorter than the palm. The rostrum is arched over the orbits, and reaches to or slightly beyond the end of the antennular peduncle, and it is rather narrow. The tip is curved upwards. The dorsal margin bears, in adult individuals, 11 to 14 teeth, regularly spaced along the margin. The first 4 to 6 teeth are located on the carapace behind the orbit. The ventral margin bears 3 to 4 teeth (Holthuis 1952).

Like A. scabra, M. carcinus is a river shrimp included in the Red List of threatened invertebrate species in Brazil. Reasons for its inclusion are over-fishing, destruction of the habitat, pollution, and construction of reservoirs (Amaral 2005). River impoundment may negatively affect river shrimps in several ways. The primary impact is that reservoirs constitute barriers to upstream migration necessary for completion of their amphidromous life cycles (Bowles et al. 2000), as is the case for M. carci- 
nus, M. acanthurus, M. olfersi (Wiegmann, 1836), and A. scabra.

Fishery: Because of its large size, $M$. carcinus is the most important species in respect to economic and social aspects in the region, where it is called "pitú". This shrimp is caught using artisanal traps, the "manzuás", baited with manioc, fish wastes, or A. scabra. Because of its high commercial value, it is generally not used as a subsistence resource, rather is preferably sold directly to the consumers or to restaurants. However, over-exploitation and loss of habitat have been responsible for the rapid decline of the formerly abundant populations of $M$. carcinus. Unfortunately there are no previous data on artisanal harvesting and population sizes for this species, but there is a consensus among the fishermen that this resource is regionally threatened with extinction. This species is of considerable economic importance in northeast Brazil and other regions of Latin America, e.g., Mexico, Venezuela, Surinam, and the Antilles (Holthuis 1980). In the United States, M. carcinus was so abundant in Texas that a commercial fishery operated during the $19^{\text {th }}$ century. Nowadays, representatives of this species are considerably more difficult to find, because of the population declines (Bowles et al. 2000).

\section{Macrobrachium heterochirus \\ (Wiegmann, 1836) (Fig. 4)}

References: Brazil - Holthuis (1952); Gomes Corrêa (1977); Bond-Buckup and Buckup (1989); Ramos-Porto and Coelho (1990); Ramos-Porto and Coelho (1998); Melo (2003); Rocha and Bueno (2004).

Material: 1f, 31.III.2004, Santana River, Ilhéus (1451'16.8”'S; 3905'58.6”W) (MZUESC\#355); 1m, 30.IV.2004, Santana River, Povoado Rio do Engenho, Ilhéus (1451'07.4”S; 3904'12.8”W) (MZUESC\#370); 2f, 13.V.2004, Santana River, Ilhéus (1451'16.8”S; 3905'58.6”W) (MZUESC\#442); 2f, 21.XII.2004, Santana River, Ilhéus (1451'16.8”S; 3905'58.6”W) (MZUESC\#451).
Distribution: United States (Florida), Mexico, Guatemala, Jamaica, Haiti, Dominican Republic, Puerto Rico, Lesser Antilles, Venezuela, and Brazil (Rio Grande do Norte, Pernambuco, Rio de Janeiro, São Paulo, Santa Catarina, and Rio Grande do Sul) (RamosPorto and Coelho 1998, Melo 2003).

Ecological notes: Usually found in riffles and low cascades, but also reported from lentic waters (Holthuis and Provenzano 1970). This species was collected in two riffle areas, with fast-flowing waters of the Santana River basin. As for A. scabra, we noted an association with the aquatic phanerogam Mourera sp.. Regarding altitudinal distribution, Hart (1961) reported the occurrence of $M$. heterochirus in Jamaica at altitudes between 75 and $530 \mathrm{~m}$. Chace and Hobbs (1969) found this species up to $750 \mathrm{~m}$ above sea level in Dominica, while Gamba (1982) reported its occurrence up to $470 \mathrm{~m}$, and between 10 and $16 \mathrm{~km}$ from the river mouth, in the same habitat as $M$. carcinus. Mejía-Ortiz et al. (2001) found reproductive females of $M$. heterochirus at altitudes from 105 to $535 \mathrm{~m}$ in Veracruz, Mexico. They also observed that the egg size varied depending on the females' physical position in river. According to Rocha and Bueno (2004), M. heterochirus belongs to a group of coastal species of Macrobrachium that depend on brackish waters to complete

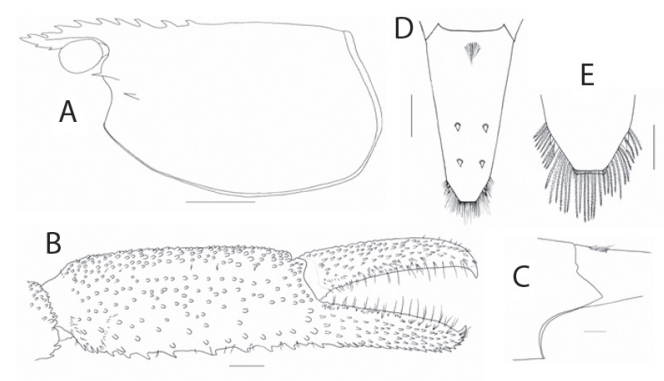

Fig. 4. Macrobrachium heterochirus (Wiegmann) from the Santana River, Ilhéus, Bahia, Brazil. A. female, not ovigerous; B-E ovigerous female. A. carapace, lateral view; B. left pereiopod 2; C. pleonite 6 and telson, lateral view; D. telson, dorsal view; E. detail of the tip of the telson. Scale bars: $\mathrm{A}=5 \mathrm{~mm}$; $\mathrm{B}, \mathrm{D}=2 \mathrm{~mm} ; \mathrm{C}, \mathrm{E}=1 \mathrm{~mm}$. 
their development. We collected specimens, including ovigerous females, at sites close to the upper tidal limit. So, this species seems to occur in a wide range of altitudes.

Remarks: The range of this species is wide, from Florida to southern Brazil, and the Antilles. On the other hand, M. heterochirus is reported by some authors as an uncommon species (Coelho 1963, Bond-Buckup and Buckup 1989, Bowles et al. 2000). There are huge gaps in the distribution of $M$. heterochirus, which include most of Central America to Venezuela, and from Venezuela to the state of Rio Grande do Norte, northeast Brazil (Ramos-Porto and Coelho 1998, Melo 2003). In eastern Brazil, another hiatus in its distribution extends from Pernambuco to Rio de Janeiro. The present record is the first from Bahia, partly filling one of the vast gaps in the geographical range of this shrimp.

The recognition characters, according to Holthuis (1952), are the following: the rostrum is narrow and straight, reaching to the base or to the end of the third segment of the antennular peduncle. The upper margin is curved on the orbits and the tip is slightly curved upwards. It bears 10 to 12 dorsal teeth, 4 to 5 behind the orbit, and 2 to 4 ventral teeth. The second pereiopods are equal in shape, though unequal in size in adult males. The fingers are much shorter than the palm; both are pubescent and provided with conspicuous spinules. The posterior margin of the telson in old specimens is truncate, ending in a spine. The inner pair of posterior spines reaches beyond the spine of the telson, but in older specimens, they are generally worn, sometimes failing to reach that far. Numerous plumose setae are found on the posterior margin.

\section{Macrobrachium jelskii (Miers, 1877) (Fig. 5)}

References: Brazil - Holthuis (1966); Gomes Corrêa (1977); Kensley and Walker (1982); Ramos-Porto and Coelho (1990); Arraes and Ramos-Porto (1994); Barros and Braun (1997); Ramos-Porto and Coelho (1998);
Melo (2003); Magalhães et al. (2005). State of Bahia - Barros and Braun (1997), Ribeirão Visagem, Contas River basin, near Gongogi (14'21'27'S, 39²5'19'W), and Córrego Pau Alto, Pau Alto River basin, Helvécia (17051'21'S, 40¹0"17'W); Dr. Angélica M.A. Corrêa (pers. comm.), Açude Rômulo Campos, Itapicuru River basin, Itiúba.

Material: 1f, 31.III.2004, Santana River, Ilhéus (1451'17.7’S; 3906’04.1”W) (MZUESC\#354); 2m, 14f, 03.II.2005, tributary of Tijuipinho River, Uruçuca (14²6'39.7'S; 39॰03'13.2"W) (MZUESC\#520); 3m, 29.XI.1997, Salgado River, Santa Cruz da Vitória (DOUFPE\#8430); 43ni (in poor state of preservation), 05.VI.1998, Piabanha River, district of Areia Branca, Jussari (DOUFPE\#9630).

Distribution: Trinidad, Venezuela, Guyana, Surinam, French Guyana, Bolívia, and Brazil (Amapá, Amazonas, Pará, Maranhão, Ceará, Rio Grande do Norte, Paraíba, Pernambuco, Alagoas, Sergipe, Bahia, Minas Gerais, Espírito Santo, Mato Grosso, São Paulo, and Santa Catarina) (Ramos-Porto and Coelho 1998, Melo 2003). Argentina (Collins 2000) and Peru (García-Dávila and Magalhães 2003).

Ecological notes: Magalhães (2000) found this species always associated with aquatic and marginal vegetation. In eastern Brazil, Barros and Braun (1997) collected M. jelskii in a wide variety of habitats, including lentic and lotic

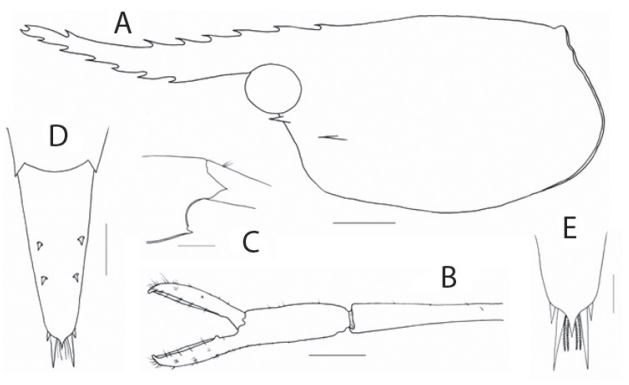

Fig. 5. Macrobrachium jelskii (Miers) from a tributary of the Tijuipinho River, Uruçuca, Bahia, Brazil, female (MZUESC\#520). A. carapace, lateral view; B. right pereiopod 2; C. pleonite 6 and telson, lateral view; D. telson, dorsal view; E. detail of the tip of the telson. Scale bars: A $=2 \mathrm{~mm} ; \mathrm{B}-\mathrm{D}=1 \mathrm{~mm} ; \mathrm{E}=0.5 \mathrm{~mm}$. 
environments, turbid and clear waters, and in rivers with abundant and sparse marginal vegetation, on muddy, sandy, and rocky bottoms. A wide environmental adaptability for $M$. jelskii was also reported by Arraes and RamosPorto (1994), who collected specimens over a wide range of altitudes ( 0 to $1200 \mathrm{~m}$ ), temperature, and types of bottom, in northeast Brazil. Our material (lots MZUESC\#354, \#520) was obtained at two collection sites with flowing water and abundant marginal vegetation.

Remarks: According to Magalhães et al. (2005), this species is endemic to tropical South America. Its distribution is very similar to that of M. amazonicum, considering either natural or human-mediated dispersal. The authors hypothesized, as for $M$. amazonicum, that this shrimp was deliberately or accidentally introduced into the Upper Paraná River basin.

In northeastern and eastern Brazil, important contributions to knowledge of the geographic range of $M$. jelskii were provided by Arraes and Ramos-Porto (1994) and Barros and Braun (1997), respectively. The latter authors reported this shrimp from localities in southeastern and southern Bahia, and from several basins in Minas Gerais and Espírito Santo. In Bahia, it is also known from the northern semi-arid region, in Açude Rômulo Campos, Itapicuru basin, like M. amazonicum (Dra. Angélica M.A. Corrêa, pers. comm.). Arraes and Ramos-Porto (1994) recorded M. jelskii in rivers and constructed reservoirs in a total of 6 states in northeast Brazil.

Some of the diagnostic characters of M.jelskii are: the slender rostrum with the tip curved upwards, reaching beyond the scaphocerite. The dorsal margin bears 6 to 7 (rarely 5 to 8 ) teeth, excluding the subapical. The first tooth is located behind the orbits, the second just above or slightly before the posterior orbital margin. The distal half is unarmed, except for the two small subapical teeth. The ventral margin bears 5 to 6 teeth. The second pereiopods are equal, slender, and entirely smooth. The fingers are slightly shorter than palm, which is cylindrical. The cutting edges of both fingers bear one proximal small tooth. The posterior margin of the telson ends in a sharp median spine, which on both sides is flanked by one pair of long inner and one pair of shorter outer spines. The inner pair distinctly overreaches the median point of the posterior margin. Four plumosae setae are found between the inner pair of spines (Holthuis 1952).

Arraes and Ramos-Porto (1994) pointed out the similarities between M. jelskii and $M$. acanthurus, considering individuals smaller than $40 \mathrm{~mm}$ in total length, while Holthuis (1952), García-Dávila and Magalhães (2003) and Magalhães et al. (2005) emphasized the resemblance to $M$. amazonicum, establishing some differential characteristics to separate the two species.

\section{Macrobrachium olfersi \\ (Wiegmann, 1836)}

References: Brazil - Ihering (1897) as Palaemon Olfersi; Ortmann (1897) as P. olfersi; Moreira (1901) as P. olfersi; Sawaya (1946); Holthuis (1952); Gomes Corrêa (1977); BondBuckup and Buckup (1989); Ramos-Porto and Coelho (1990); Arraes and Ramos-Porto (1994); Barros and Braun (1997); RamosPorto and Coelho (1998); Melo (2003); Rocha and Bueno (2004). State of Bahia - Ihering (1897) as P. olfersi; Holthuis (1952), "Ilheos (sic) south of Bahia"; Gomes Corrêa (1977), Ilhéus; Barros and Braun (1997), Burunhém (sic) River (=Buranhém), $8 \mathrm{~km}$ south of Vera Cruz, between Eunápolis and Porto Seguro (16 $25^{\prime} 28^{\prime}$ 'S, 39 $\left.21^{\prime} \mathrm{W}\right)$, and Jucuruçu River,

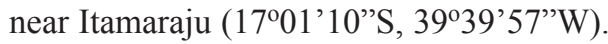

Material: 3m, 30.III.2001, Cachoeira River, Ilhéus (1448'05.18”S; 3909'54.49”W) (MZUESC\#108); 7m, 1f, 07.VIII.2001, Cachoeira River, Ilhéus (1448'10.33"S; $\left.39^{\circ} 10^{\prime} 03.65^{\prime \prime} \mathrm{W}\right) \quad$ (MZUESC\#112); 2m, 10.VII.2001, Cachoeira River, Ilhéus (144ㅇ'10.33”S; $\left.\quad 39^{\circ} 10^{\prime} 03.65^{\prime \prime} \mathrm{W}\right)$ (MZUESC\#114); 1f, 11.III.2003, Cachoeira River, Ilhéus (1447’31.6”S; 39¹1'07.8”W) (MZUESC\#116); 2m, 27.II.2004, Cachoeira River, Ilhéus (1448'05.18”S; 3909'54.49”W) (MZUESC\#333); 28m, 59f, 11.III.2004, 
small stream, Serra Grande, Uruçuca (14²7'S; $\left.39^{\circ} 01^{\prime} \mathrm{W}\right) \quad$ (MZUESC\#347); $17 \mathrm{~m}$, 9f, 31.III.2004, Santana River, Ilhéus (1451'16.8”'S; 3905'58.6”W) (MZUESC\#356); 15m, 26f, 15.IV.2004, Santana River, Ilhéus (1451'16.8”S; 3905'58.6”W) (MZUESC\#358); 3m, 1f, 14.IV.2004, Lagoa Encantada, Ilhéus (14³7'20.8'S; 39॰08'32.5”'W) (MZUESC\#363); $1 \mathrm{~m}$, 30.IV.2004, Santana River, Povoado Rio do Engenho, Ilhéus (1451'07.4”S; 3904'12.8”W) (MZUESC\#369); 1m, 2f, 06.IV.2004, Acuípe

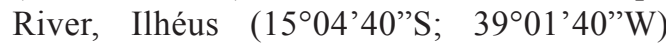
(MZUESC\#376); 2m, 2f, 12.V.2004, Lagoa Encantada, Ilhéus (14³7'20.8”'S; 39॰08'32.5”W) (MZUESC\#440); 17m, 45f, 20.V.2004, Santana River, Fazenda Theobroma, Ilhéus (1450'58.2”S; 3904'52.7”W) (MZUESC\#445); 3f， 02.II.2005, small stream, Estação Experimental da CEPLAC, Una $\quad\left(15^{\circ} 17^{\prime} 02.3^{\prime \prime} \mathrm{S} ; \quad 39^{\circ} 05^{\prime} 21.5^{\prime \prime} \mathrm{W}\right)$ (MZUESC\#514); 3m, 10f, 02.II.2005, Aliança

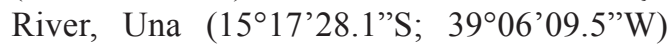
(MZUESC\#517); 11m, 10f, 03.II.2005, Tijuipinho River, Uruçuca (14²6'39.7”S; 39०03'13.2"W) (MZUESC\#522); 1f, 22.II.2005,Almada River, Ilhéus (14³9'09.6”'S; 3904'58.7'W) (MZUESC\#528); not quantified (poor state of preservation, some large male chelae preserved), 28.V.1999, Cachoeira River, Salobrinho, Ilhéus (DOUFPE\#5354); 1m, 30.VI.1999, Cachoeira River, Ilhéus (DOUFPE\#5355); 1m, 24.XI.1997, Sete Voltas River, Ilhéus (DOUFPE\#9944); 2m, 1f, 05.VI.1998, Piabanha River, district of Areia Branca, Jussari (DOUFPE\#9949); 5m, 27.XI.1997, Represa da Mata da Esperança, Parque Municipal da Boa Esperança, Ilhéus (DOUFPE\#9955).

Distribution: United States (North Carolina, Florida, Texas), Mexico, Central America, Colombia, Venezuela, Guyana, Surinam, and Brazil (Pará, Piauí, Ceará, Rio Grande do Norte, Pernambuco, Alagoas, Sergipe, Bahia, Minas Gerais, Espírito Santo, Rio de Janeiro, São Paulo, Paraná, Santa Catarina, and Rio Grande do Sul) (RamosPorto and Coelho 1998, Melo 2003).
Ecological notes: $M$. olfersi is found in estuaries and mangroves as well as in freshwater streams (Coelho 1963). Barros and Braun (1997) collected this shrimp in Bahia in streams with vegetation along the banks and sandy bottoms. Gamba (1982) commented that adults of $M$. olfersi and $M$. carcinus were collected in Venezuela at altitudes up to $140 \mathrm{~m}$, but in different habitats: while $M$. carcinus prefer to hide between the rocks in riffles, $M$. olfersi lives on stony streambeds, hidden behind the vegetation. Post-larvae and juveniles were sampled at salinities up to 36 . This species was collected $35 \mathrm{~km}$ from the coast in Venezuela (Gamba 1982). An exceptionally distant record was given by Rodríguez-Almaraz and Campos (1996) in Mexico: $205 \mathrm{~km}$ from the river mouth. Rocha and Bueno (2004) examined material from São Paulo state, also collected far from the coast. They believed that these populations were distant from the estuaries, to more effectively contribute larvae to recruitment. In the study area, $M$. olfersi was obtained on sandy bottoms, associated with marginal vegetation, in either flowing or lentic waters (e.g., Lagoa Encantada), as well as on stony streambeds.

Remarks: This species is widely distributed from North Carolina to southern Brazil. The first report from Bahia was provided by Ihering (1897), without mention of the locality of collection. Records since then are few (Holthuis 1952, Gomes Corrêa 1977, Barros and Braun 1997).

The main diagnostic characters of $M$. olfersi are the following: the rostrum is straight or bent slightly downwards; the upper margin bears 12-15 regularly spaced teeth, 4 or 5 of which are located on the carapace behind the orbit; the lower margin bears 3, rarely 4 teeth; the posterior margin of the telson ends in an acute point, overreached by the inner pair of posterior spines; the pereiopod 2 is very unequal; the larger pereiopod 2 reaches with the entire carpus and a small part of the merus beyond the scaphocerite; the fingers, especially the dactylus, are strongly curved, gaping thereby; the palm is slightly compressed and 
somewhat swollen, the upper and lower margins are convex; the palm is 1.5 times to almost twice as long as high and about as long as the fingers; the inner, outer, and lower surfaces of the palm are covered by a dense pubescence; the upper portion is devoid of pubescence; scattered stiff hairs are present (Holthuis 1952).

Macrobrachium olfersi is part of a group of closely related species denominated the "olfersi group", especially regarding the morphology of the second pair of pereiopods (Villalobos 1969). Among the Brazilian Macrobrachium species, the following are closely related to M. olfersi: M. holthuisi Genofre and Lobão, 1978, M. birai Lobão, Melo and Fernandes, 1988, and M. denticulatum Ostrovski, Fonseca and Silva-Ferreira, 1996. The dentition pattern of the rostrum is also very similar among the 4 species, which makes it difficult to distinguish them. Detailed information regarding the distinction between $M$. olfersi and the other 3 related Brazilian species can be obtained in Genofre and Lobão (1978), Melo et al. (1988), and Ostrovski et al. (1996).

The distributions of the endemic $M$. holthuisi, M. birai, and M. denticulatum are as follows: M. holthuisi is known from Espírito Santo and São Paulo; M. birai from Piauí to Rio Grande do Norte, Alagoas, Sergipe, and São Paulo; and M. denticulatum is restricted at present to the semi-arid part of the São Francisco River basin, including records in northern Bahia (Melo 2003).

Fishery: This shrimp is still common in the study area, where it is known by the common name "aratanha". The species is smaller in size compared to $M$. carcinus and $M$. acanthurus. Thus, it is of secondary economic importance in the Cachoeira River basin. $M$. olfersi is mainly used as food and bait by riverine populations, but also is found in markets. Interest in the capture of this shrimp is also increasing because of the decline of $M$. carcinus populations. This species was easily trapped in the "manzuás" using manioc as bait. Holthuis (1980) commented on the local importance of $M$. olfersi as food in Venezuela and in northeast Brazil.

\section{Palaemon (Palaemon) pandaliformis \\ (Stimpson, 1871) (Fig. 6)}

References: Brazil - Ortmann (1897) as Leander potitinga Müller, 1880; Ihering (1897) as L. potitinga; Moreira (1901) as L. potitinga; Sawaya (1946) as Palaemon potitinga; Holthuis (1952); Coelho and Ramos (1972); Gomes Corrêa (1977); Bond-Buckup and Buckup (1989); Ramos-Porto and Coelho (1990, 1998); Melo (2003); Rocha and Bueno (2004). State of Bahia - Melo (2003); Almeida et al. (2006), Ilhéus, Acuípe River estuary (1504'53.6”'S; 39॰00'13.8”'W).

Material: 27f, 05.X.2002, Lagoa Encantada, Ilhéus (14³7’02.5”S; 39॰07'44.6”W) (MZUESC\#105); 3m, 8f, 2ni, 01.IV.2004, Lagoa Encantada, Ilhéus $\quad\left(14^{\circ} 37^{\prime} 20.8^{\prime \prime} \mathrm{S} ; \quad 39^{\circ} 08^{\prime} 32.5^{\prime \prime} \mathrm{W}\right)$ (MZUESC\#351); 7m, 19f, 01.IV.2004, Lagoa Encantada, Ilhéus (14³7'02.5”S; 39॰07'44.6” (M) (MZUESC\#352); 52m, 124f, 14.IV.2004, Lagoa Encantada, Ilhéus $\quad\left(14^{\circ} 37^{\prime} 20.8^{\prime \prime} \mathrm{S} ; \quad 39^{\circ} 08^{\prime} 32.5^{\prime \prime} \mathrm{W}\right)$ (MZUESC\#361); 17m, 61f, 12.V.2004, Lagoa Encantada, Ilhéus (14³7'20.8”'S; 39॰08'32.5”'W) (MZUESC\#441); 3m, 5f, 22.II.2005, Almada River, Ilhéus (14³9’09.6”'S; 3904'58.7'W) (MZUESC\#527).

Distribution: Cuba, Puerto Rico, Barbados, Trinidad, Guatemala, Nicaragua,

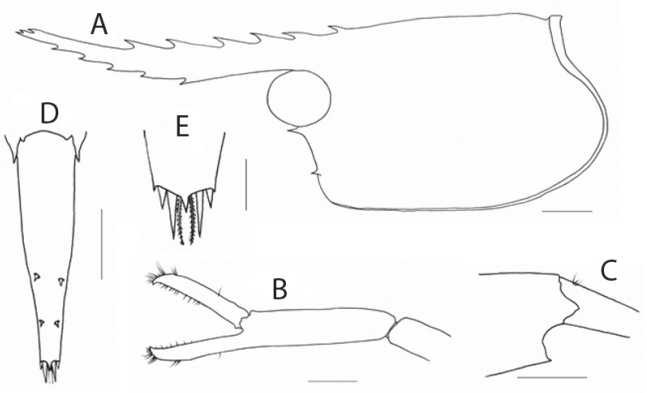

Fig. 6. Palaemon (Palaemon) pandaliformis (Stimpson) from Lagoa Encantada, Ilhéus, Bahia, Brazil, ovigerous female (MZUESC\#361). A. carapace, lateral view; B. pereiopod 2; C. pleonite 6 and telson, lateral view; D. telson, dorsal view; E. detail of the tip of the telson. Scale bars: A, C, D = $1 \mathrm{~mm}$; $\mathrm{B}=0.5 \mathrm{~mm} ; \mathrm{E}=0.25 \mathrm{~mm}$. 
Panama, Venezuela, and Brazil (Rio Grande do Norte, Sergipe, Bahia, Minas Gerais, Espírito Santo, Rio de Janeiro, São Paulo, Paraná, Santa Catarina, and Rio Grande do Sul) (Melo 2003).

Ecological notes: Found in fresh and brackish water, frequently associated with the roots of marginal vegetation (Bond-Buckup and Buckup 1989), also on mud bottoms (RamosPorto and Coelho 1990). Almeida et al. (2006) collected this species in a mangrove area, in pools among the roots of Rhizophora mangle (Linnaeus, 1753). We collected this species in the Almada River basin (Almada River and Lagoa Encantada), in slow to lentic waters, always associated with herbaceous vegetation along the banks.

Remarks: This small shrimp has been recorded in waters of the Atlantic slope in Central America, Antilles, and Brazil (from Rio Grande do Norte to Rio Grande do Sul), not being reported for the northern Brazilian states (Ramos-Porto and Coelho 1990, Melo 2003). Melo (2003) cited its occurrence in Bahia, but provided no information on collection sites.

The other 3 species of Palaemon from Brazil are marine: $P$. (Palaemon) ritteri Holmes, 1895; P. (Palaemon) paivai Fausto Filho, 1967; and P. (Palaeander) northropi (Rankin, 1898) (Ramos-Porto and Coelho 1990, 1998). The last is also known for Bahia (Ramos-Porto and Coelho 1990, Almeida et al. 2006).

In the genus Palaemon Weber, 1795, in contrast to Macrobrachium, the hepatic spine is absent and the branchiostegal spine is present (Holthuis 1952, Bond-Buckup and Buckup 1989, Melo 2003). Specific recognition characters of $P$. (Palaemon) pandaliformis are: rostrum slender, reaching beyond the scaphocerite, with the distal portion slightly directed upwards; the dorsal rostral margin provided with $5-7$, rarely 8 , teeth in the proximal $3 / 5$ of its length, the first of them located behind the orbit; last $2 / 5$ free for 1 or 2 , rarely 3 , subapical teeth; ventral rostral margin with 5-8, generally 6 , rarely 9 teeth; pleura of the fifth abdominal somite is rather narrow, produced posteriorly, ending in a rounded tip; posterior margin of the telson is distinct, ending in a sharp median point, flanked by the usual 2 pairs of spines and 1 pair of feathered setae; the inner pair of spines distinctly overreaches the median point of the telson; mandible with a three-jointed palp; second pair of pereiopods is very slender, only slightly less slender than the first pair; the fingers are slightly shorter than the palm, and 1 small tooth is present on the cutting edge of the dactylus (Holthuis 1952, Melo 2003).

Fisheries: No commercial interest in the region, but it is commonly used as fishing bait in northeast Brazil (Holthuis 1980).

Infraorder Brachyura Latreille, 1802

Superfamily Portunoidea Rafinesque, 1815

Family Portunidae Rafinesque, 1815 Callinectes bocourti

A. Milne-Edwards, 1879

References: Brazil - Moreira (1901); Rathbun (1930); Coelho and Ramos (1972); Williams (1974); Coelho and Ramos-Porto (1992); Melo (1996, 1998); Calado and Sousa (2003). State of Bahia - Moreira (1901); Rathbun (1930), Cannavierias (sic) (= Canavieiras); Williams (1974), Ilhéus; Almeida et al. (2006, 2007), Ilhéus (Santana and Cachoeira River estuaries), and Camamu Bay, respectively.

Material: 1m, 28.III.2001, Cachoeira River, Ilhéus (1448'05.18”S; 3909'54.49”W) (MZUESC\#6); 1m，3f，22.II.2005, Almada River, Ilhéus (14³9'46.7”S; 3904'53.2”W) (MZUESC\#575);

Distribution: Western Atlantic - east coast of the United States, Antilles, northern South America, and Brazil (from Amapá to Rio Grande do Sul) (Melo 1996, Santos et al. 2000).

Ecological notes: Estuarine species that apparently prefers low-salinity environments, occasionally occurring in freshwater (Taissoun 1973, Williams 1974, Powers 1977, Melo 1996). This crab occurs from shallow waters to $20 \mathrm{~m}$ deep (Melo 1996). Williams (1974) reported an apparent association between $C$. bocourti 
and C. sapidus Rathbun, 1895 in estuarine areas, but he observed that $C$. bocourti seems to be more tolerant of stagnant polluted waters. Also reported in mangroves, inhabiting mud to sandy bottoms, and pools inside porous old coral rubble (see Williams' 1974 review).

Remarks: $C$. bocourti belongs to the Antillean Continuous pattern of distribution, with a wide latitudinal distribution in western Atlantic estuaries, from Florida to southern Brazil, including Central America and the Antilles (Melo 1985, 1996).

Almeida et al. (2006) reported this species from estuarine waters in the study area. We report herein the occurrence of 5 adults (males and females) in fresh water, which demonstrates, once more, the high degree of tolerance of this species to salinity variations.

The main diagnostic characters of $C$. bocourti are: the frontal region is armed with 4 triangular teeth between the inner orbitals; the submesial pair of frontal teeth are well developed, as long as the lateral pair; the anterolateral margins are moderately arcuate; the anterior margin of anterolateral teeth is shorter than the posterior margin; the lateral carapace spine is swept forward, weakly developed compared to the other anterolateral spines; the dorsal surface of the carapace is smooth; the chelipeds are remarkably smooth except for the usual spines and obsolescent granules on the ridges. Adult males are easily recognizable by the extreme length of the first gonopods, that often exceed the telson and cross near their tips (Williams 1974, Melo 1996).

Fisheries: Portunids of the genus Callinectes are much appreciated in northeast Brazil cuisine (Calado and Sousa 2003). Callinectes bocourti is caught in brackish waters with an artisanal trap called "siripóia", and is used as food, like other species of Callinectes in the region. In the Cachoeira and Almada rivers it is a subproduct of the Macrobrachium fishery, being occasionally trapped in "manzuás".

\section{Callinectes sapidus \\ Rathbun, 1895}

References: Brazil - Rathbun (1930); Coelho and Ramos (1972); Williams (1974); Melo (1985); Melo et al. (1989); Coelho and Ramos-Porto (1992), Melo (1996, 1999), Calado (2000). State of Bahia-Rathbun $(1896,1930)$, as C. sapidus acutidens Rathbun, 1895, Santa Cruz (= Santa Cruz Cabrália), Thayer Expedition; Almeida et al. (2006), Ilhéus, Cachoeira River estuary (1448'51'S;39 $03^{\circ} 27.4^{\prime \prime} \mathrm{W}$ and 1448'00.7’S; 3905'29.8’'W).

Material: 1f, 11.II.2001, Contas River, district of Taboquinhas, Itacaré $\left(1^{\circ} 20^{\prime} \mathrm{S}\right.$; $39^{\circ} 10^{\prime} \mathrm{W}$ ) (MZUESC\#117); 1m, 3f, XII.2003, Lagoa Encantada, Ilhéus (14³7'12.5”S; 3908'32.5'W) (MZUESC\#314).

Distribution: Western Atlantic - Bermuda, Nova Scotia, east coast of the United States, Antilles, Central America, Venezuela, and Brazil (from Alagoas to Rio Grande do Sul) to Argentina. Eastern Atlantic - from Cape Verde to Angola. Denmark, Netherlands, and adjacent North Sea. Mediterranean, Adriatic, Aegean, and Black seas. West Pacific - Japan (Williams 1974, Melo 1996, 1999, Calado 2000).

Ecological notes: The blue crab C. sapi$d u s$ is a coastal species, tolerant of extremes of salinity and temperature. This portunid has been found in fresh water, estuaries, bays, ponds, ditches, shallow ocean water to $90 \mathrm{~m}$ (more commonly to $35 \mathrm{~m}$ ), and hypersaline lagoons (Williams 1974, Powers 1977). It is also found in very polluted and anoxic waters, with low oxygen levels (Powers 1977, Melo 1999). Sometimes males are found well upstream in larger rivers (Powers 1977). Large males were collected 180 miles from the sea in Florida (Williams 1974). In Alagoas, Brazil, Calado (2000) reported the occurrence of adult males about $100 \mathrm{~km}$ from the coast. Females seem to prefer shallow water off ocean beaches.

Remarks: Among the Brazilian portunids, C. sapidus is the only one that shows a modern 
disjunct pattern of distribution in the western Atlantic - a northern group occurs from the east coast of the United States to Venezuela; and a southern group occurs from northeastern Brazil to Argentina (Williams 1974, Melo 1996, Calado 2000, Santos and D'Incao 2004). Possible causes of the disjunct distribution of $C$. sapidus in the western Atlantic were discussed by Santos and D'Incao (2004). Introduction in other parts of the world is probably a result of transport in the ballast tanks of ships (Williams 1974, Santos and D'Incao 2004).

The occurrence of this crab in Bahia is documented in few contributions. Rathbun (1896) described the subspecies C. sapidus acutidens, based on material collected by the Thayer Expedition in Santa Cruz (Santa Cruz Cabrália, near Porto Seguro). This taxon was included by Williams (1974) in the list of synonyms of $C$. sapidus. More recently, the species was reported from the estuaries of Ilhéus by Almeida et al. (2006).

This portunid is easily distinguishable from any other Callinectes species because it has the frontal region armed with two prominent, broad-based triangular teeth between the inner orbitals, although rudimentary submesial teeth may be present on the mesial slope. The frontal teeth may be obtuse or acuminate in shape. Other diagnostic characteristics are: the anterolateral margins are slightly arched; the anterolateral teeth and the lateral spine are obtuse or acuminate and directed more outward than forward. Much of the carapace surface is smooth, with scattered granules, but granules are concentrated locally on the mesobranchial, posterior slope of the cardiac, and on the anterior portion of mesogastric area. The propodus and carpus of the chelipeds have moderate, finely granulate ridges. The male abdomen and telson reach about midlength of thoracic sternite IV. The first male gonopods are very long, reaching beyond the suture between thoracic sternites IV and V but not exceeding the telson (Williams 1974, Melo 1996).

Fisheries: The blue crab is harvested throughout its range, and is considered the most valuable species of Callinectes in commercial fisheries, mainly in the northern hemisphere (Williams 1974). In southeast Bahia, it is caught in brackish waters, with other Callinectes species, for commercial or home use. In the Contas River, and probably the Cachoeira and Almada rivers, like $C$. bocourti it is also a subproduct of Macrobrachium fisheries.

Family Trichodactylidae Milne-Edwards, 1853 Trichodactylus fluviatilis

Latreille, 1828 (Figs. 7-8)

References: Brazil - Göldi (1886), Moreira (1901); Rathbun (1906); Melo (1967); Bott

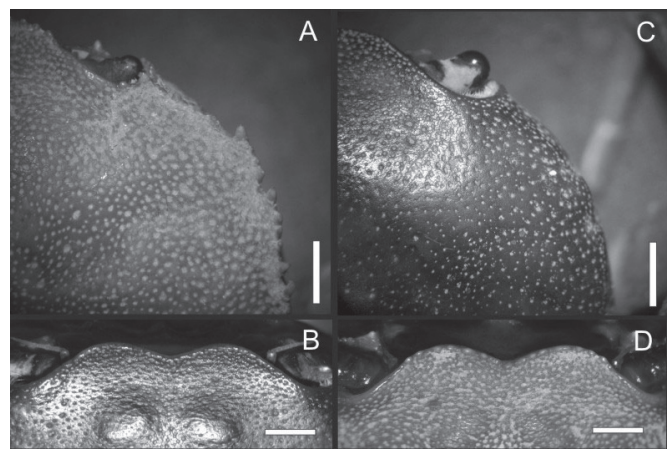

Fig. 7. Trichodatylus fluviatilis Latreille, from the Ribeirão Serafim, Santana River basin, Ilhéus, Bahia, Brazil. A. female ("form A") (MZUESC\#452), detail of the anterolateral margin of carapace; B. same, detail of the frontal margin; C. male ("form B") (MZUESC\#956), detail of the anterolateral margin of carapace; D. same, detail of the frontal margin. Scale bars: $2 \mathrm{~mm}$.
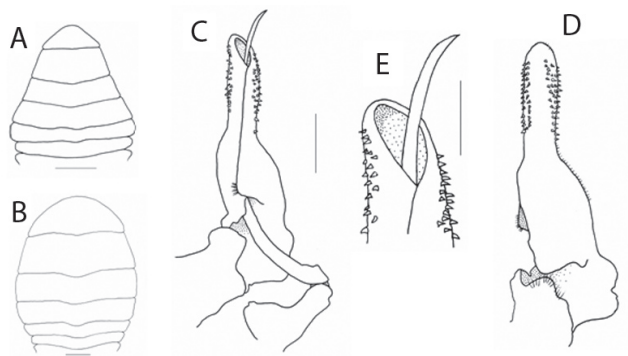

Fig. 8. Trichodatylus fluviatilis Latreille, from the Ribeirão Serafim, Santana River basin, Ilhéus, Bahia, Brazil (MZUESC\#452). A. male abdomen; B. female abdomen; C. left gonopods 1 and 2, mid-ventral view; D. right gonopod 1, dorsal view; E. left gonopod 1, detail of the tip. Scale bars: $A, B=5 \mathrm{~mm} ; C, D=2 \mathrm{~mm} ; E=1 \mathrm{~mm}$. 
(1969); Rodríguez (1992), Magalhães (1991, 1998, 1999, 2003); Rocha and Bueno (2004).

State of Bahia - A. Milne-Edwards (1869), type material of T. crassus; Moreira (1901) as T. crassus; Rathbun (1906) as $T$. (Trichodactylus) crassus; Melo (1967) as T. (Trichodactylus) fluviatilis, Ilhéus; Bott (1969) as T. (Trichodactylus) fluviatilis crassus; Magalhães (1991) as T. (Trichodactylus) fluviatilis, several localities; Magalhães (1998, 2003).

Material: 1m, 1f, collected between VIII.2002 and VIII.2003, small stream, Fazenda Alto Bela Vista, Serra da Palha, Coaraci (MZUESC\#233); 3m, 3f, 21.XII.2004, Ribeirão Serafim, Santana River basin, Tranqüilidade, Ilhéus (14 51 '18"S; 3906'04”W) (MZUESC\#452); 1f, 02.II.05, small stream, Estação Experimental da

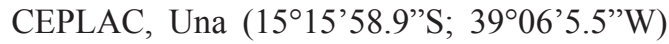
(MZUESC\#513); 7m, 4f, III.2006, Ribeirão Serafim, Santana River basin, Tranqüilidade, Ilhéus (1451'18”S; 3906”04”W) (MZUESC\#956); 2f, III.2000, Água Preta River, Itajú do Colônia (DOUFPE\#8729); 2m, 2f, III.2000, Rio do Meio, Itororó (DOUFPE\#8730); 1f, 1919, Cachoeira River, Itabuna (MZUSP\#2303); 1m, 17.III.1988, Fazenda Unacav, Buerarema (perhaps Fazenda Unacau, today in the municipality of São José da Vitória) (MZUSP\#9698); 1m, 1f, 26.XI.1989, CEPLAC, Ilhéus (MZUSP\#10784); 1m, 1f, 26.XI.1989, CEPLAC, Ilhéus (USU\#1515); 2m, 26.V.1994, Almada River, district of Castelo Novo, Ilhéus (USU\#1525); 2m, 4f, 25.V.1994, Fazenda Quatro Irmãos, IlhéusUruçuca (perhaps on the road between Ilhéus and Uruçuca) (USU\#1533); 1m, 1f, 23.V.1994, Almada River, Ilhéus (USU\#1534); 3m, 6f, 15.II.1996, Fazenda Serrapilheira, district of Castelo Novo, Ilhéus (USU\#1568).

Additional material: State of Pernambuco - 1f, 14.VI.1999, Brejo de Vila, Gravatá (DOUFPE\#8728); 1m, no date available, Amaraji River, Gravatá (DOUFPE\#8731); State of Alagoas - 2m, 1f, XI.1993, stream, Mata do Cedro, Rio Largo (DOUFPE\#13560); $3 \mathrm{~m}$, I.1987, Murici (USU\#1513); State of
Bahia - 2f, 04.X.2001, Estação Estadual de Wenceslau Guimarães, Wenceslau Guimarães (MZUESC\#191); 2m, 1f, 05.I.2003, small stream, Fazenda Camamu, Camamu (MZUESC\#192); 2m, 2f, 07.X.1987, Prado (MZUSP\#10782); 2m, 30.VII.1989, road to Tororão (Beach), Prado (MZUSP\#10783); 1m, 01.VIII.1989, Maracás (USU\#1511); 4m, 30.VII.1989, road to Tororão (Beach), Prado (USU\#1518); 4f, 13.VI.1994, Una River, Chapada Diamantina, Itaeté (USU\#1519); 3m, 3f, 07.X.1987, Prado (USU\#1521); 8m, 7f, 13.VI.1994, Una River, Chapada Diamantina, Itaeté (USU\#1522); 4f, 13.VI.1994, Una River, Chapada Diamantina, Itaeté (USU\#1527); 2m, 4f, 13.VI.1994, Una River, Chapada Diamantina, Itaeté (USU\#1528); 1m, 1f, 13.VI.1994, Una River, Chapada Diamantina, Itaeté (USU\#1529); 1m, 10.VI.1994, Brejo de Marimbús, Remanso, Chapada Diamantina, Lençóis (USU\#1531); 1m, 10.VI.1994, Brejo de Marimbús, Remanso, Chapada Diamantina, Lençóis (USU\#1532); 2m, 13.VI.1994, Una River, Chapada Diamantina, Itaeté(USU\#1536); 1m, 13.VIII.1989, Esplanada (USU\#1537); 2f, 15.VIII.1989, Fazenda da Tiririca, Conde (USU\#1538); State of Espírito Santo - 4m, I.1964, Santa Tereza (MZUSP\#1749); 2m, 1f, 02.IV.1969, Córrego Lombardia, Santa Tereza (MZUSP\#6374); 1m, 2f, 1juv, I.1989, Santa Tereza (USU\#1543); 2m, 1f, I.1989, Santa Tereza (USU\#1544); State of Minas Gerais - 2m, 1f, 06.II.1987, Conceição de Ibitipoca (USU\#1535).

Distribution: Brazil - from Pernambuco to Rio Grande do Sul (Magalhães 2003).

Ecological notes: In rivers and streams, usually found among and under rocks (Magalhães 2003).

Remarks: Species endemic to Brazil, recorded in all Brazilian coastal states between Pernambuco and Rio Grande do Sul, and also inland in Minas Gerais (Magalhães 1998, 2003). This crab is distributed along hydrographic basins of the Atlantic slope, in the area coincident with the original extension of the Atlantic rainforest, and in the Upper Paraná River basin (Magalhães 2003). 
Diagnostic characters: The shape of the carapace varies from subquadrate to pyriform, and is moderately flat to convex. The frontal region is bilobed, slightly inclined downwards, usually smooth, sometimes provided with granules. The anterolateral margin of the carapace is smooth or indistinctly carinate, with 1-3 notches (generally 2) or 1-2 small teeth present. The male abdomen is subtriangular, and the width of the posterior margin of the sixth abdominal somite coincides with the anterior margin of the telson. The male gonopod is straight, with a more or less pronounced median constriction. The spine fields are discontinuous, arranged in two sub-equal areas on the ventro-lateral and dorso-mesial surfaces. The marginal suture is straight, located on the mesial surface. The apical region is symmetrical; the form of the distal border varies from rounded to slightly angular. The distal opening is in general broad and obliquely directed toward the mesial surface (Magalhães 2003). The chelipeds are unequal in size, in both sexes, the right one being longer and stronger than the left one. This pronounced heterochely is more evident in larger specimens, especially in males (Melo 1967).

Concerning the taxonomy, there are still problems in clearly separating the Brazilian forms around T. fluviatilis. The characters related to dentition and the shape of the carapace show very high intraespecific variability in a number of trichodactylid genera, do not aid in the classification of these crabs, and are used as secondary characters in the identification of some species groups (Magalhães and Türkay 1996).

Such variations in morphological characters relative to the carapace have been noticed by earlier authors (Göldi 1885, 1886, Rathbun 1906). Melo (1967) examined material of $T$. fluviatilis from 22 localities from Bahia to Santa Catarina, in order to study geographical differentiation and sexual dimorphism, based on body proportions and meristic characters. He reported that 14 of the 16 characters studied showed a large amount of variation but with no distinct geographical pattern, concluding that the characters vary in a largely independent way. Magalhães (1991), studying a large amount of T. fluviatilis material, also observed the extremely irregular distribution of the variability, especially in the dentition and degree of convexity of the carapace. Moreover, although some slight variation could be noticed, the gonopods had an uniform structure, characterized by large and oblique distal openings. He judged it to be more convenient to treat the species as a complex of related forms. Rodríguez (1992) characterized two distinct groups of $T$. fluviatilis: (A) individuals with the carapace tending toward a square shape, its surface flattened and irregular, the branchial region flattened or concave, and the lateral margins sharp, provided with 2 (rarely 3 ) notches; the frontal margin is visible in dorsal view; the lower orbital margin has distinct granules; (B) individuals with the carapace more orbicular in shape, its surface less irregular, the branchial region clearly convex, and the lateral margins rounded and smooth, devoid of teeth; the frontal margin not visible in dorsal view; the lower orbital margin with smaller granules.

However, during the preliminary examination of the material deposited at MZUESC, some extreme morphological variations among the specimens were observed, especially in the lateral margin of the carapace, the frontal margin, and the orbits. These observations stimulated a broader analysis, comparing material from other localities in Bahia, and from other states.

Two basic forms were distinguished in material of $T$. fluviatilis collected in the study area: form A - characterized by the frontal margin of the carapace bordered by conspicuous granules, the anterolateral margin provided with developed teeth plus granules, and the posterolateral margin provided with granulation similar to that found on the front (Figs. 7A, B, 8); form B - characterized by the frontal margin smooth or with inconspicuous granulation; the anterolateral margin usually provided with 1-3 notches, teeth (1-2), if present, small; and the posterolateral margin smooth or slightly granulated (Figs. 7C, D). 
Characterization of form $A$ (Figs. 7A, B, 8): The frontal margin is bordered by a series of conspicuous granules. The exorbital angle is armed with an acute, sometimes rhombic tooth. The lateral margin of the orbit is generally bordered with a series of small, closely spaced, similarly sized teeth, while the lower margin of the orbit is usually unarmed, sometimes provided with vestigial denticles. The upper margin has 2-3 denticles, irregularly distributed. The inner orbital angle ends in a conspicuous tooth, generally rhombic, visible in dorsal view.

The anterolateral margin of the carapace is provided with 3 well-developed spiniform, forwards-directed teeth. These teeth are preceded by a large U-shaped sinus (= notches), and sometimes are provided with an accessory tooth. Denticles and granules are present between the exorbital tooth and the first anterolateral tooth, and between the other teeth themselves. In some specimens from the Santana River (MZUESC\#452) a spine-shaped tooth is present, closer to the third rather than the second, directed outwards, as a fourth spine (Fig. 7A). The denticles and granules vary in number and distance from each other. These variations confer a certain asymmetry between the opposite anterolateral margins. The posterolateral margin is carinate and bordered with granules, which gradually decrease in size in the last $1 / 3$ of its length. The oral crest is usually armed with obtuse denticles.

The carapace tends to be flat. It has strong punctuation and is sometimes hairy, especially in smaller individuals. Two gastric elevations are conspicuous on the anterior half, and a generally well-marked $\mathrm{H}$-shaped sulcus is present on the posterior one.

The chelipeds are smooth, but punctuated. The carpus, as usual for the species, is provided with a forwards-directed spiniform tooth on its inner surface; and with a small distal tooth on the merus dorsal surface. The ventral surface of the merus, in most cases, is provided with two irregular marginal lines (inner and outer) of denticles and granules, some of which may be rudimentary or absent. The inner line generally continues in the ischium.
The male abdominal and gonopodal characters agree well with the diagnosis provided by Magalhães (2003).

The most typical representatives of this form are the extreme spinulated specimens obtained in the Santana River basin, Ilhéus (MZUESC\#452) (Figs. 7A, B, 8): 3m $(\mathrm{CLxCW}=22.4-26.9 \times 24.8-30.9 \mathrm{~mm})$ and $3 \mathrm{f}$ $(\mathrm{CLxCW}=24-33.7 \times 27.6-38.4 \mathrm{~mm})$. Part of lot MZUESC\#956, 2m (30.9x35.5 and 23.2x26.1 $\mathrm{mm}$ CLxCW) and 2 females $(29.5 \times 34.9$ and $28.5 \times 32 \mathrm{~mm}$ CLxCW), collected at the same site, agree well with the characteristics of form A described above. The other 7 individuals of this lot are within form B or are "intermediate" forms (see below).

The female specimen $(\mathrm{CLxCW}=$ $29.4 \times 36.7 \mathrm{~mm}$ ) (MZUSP\#2303) collected by Ernst Garbe in his travels in southeast Bahia in 1919 (Garbe 1920), in the Cachoeira River, Itabuna, was identified as Trichodactylus sp. by Dr. Célio Magalhães. This specimen has the front, part of the left upper orbital margin, and the posterior region of the carapace damaged. Most of the spiniform teeth on the anterolateral margin of the carapace have broken apices. However, the granulation on part of the upper orbit and on the posterolateral margin of the carapace, and the dentition pattern on the anterolateral margin are typical of form A, closely resembling the specimens from the Santana River (MZUESC\#452). Also the carapace and outer cheliped surface are largely punctuated. The ventral surface of the merus of the chelipeds is provided with two irregular marginal lines (inner and outer) of denticles and granules.

The material from the Almada River basin (USU\#1534) is closely related to the specimens from the Santana (MZUESC\#452) and Cachoeira River (MZUSP\#2303) basins. The specimens, one female $(\mathrm{CLxCW}=26.7 \times 30.9$ $\mathrm{mm})$ and one male $(\mathrm{CLxCW}=23.8 \times 27 \mathrm{~mm})$, resemble the smaller individuals from lot MZUESC\#452 in the degree of dentition of the front, lateral margin of carapace, and orbit. Also, 3 characteristic U-shaped notches are present on the anterolateral margin of the carapace. 
The larger female of lot DOUFPE\#8729 $(\mathrm{CLxCW}=25.3 \times 29 \mathrm{~mm})$, from the Água Preta River, Itaju do Colônia, agrees with the characteristics described for form A. The carapace margin is entirely granulated. Three anterolateral spines are present, although smaller than those found in the specimens of lot MZUESC\#452. Three shallow notches are present. The carapace near the front is densely punctuated; the gastric elevations are pronounced; the frontal margin and the upper, lateral, and inferior margins of the orbits are finely granulated. The characteristics of the smaller female of this lot $(\mathrm{CLxCW}=15.9 \times 18.3$ $\mathrm{mm}$ ) are similar in general form to the larger female, however its front is smoother, and the third anterolateral notch is absent.

Also assignable to this form are the specimens from lot DOUFPE\#8730, from Rio do Meio, Itororó. The carapace of the larger male $(\mathrm{CLxCW}=30.5 \times 35.9 \mathrm{~mm})$ is rather smooth, but dense punctuation can be observed in the frontal region. The anterolateral margin is provided with 3 spines. Three notches are also present. The first one is U-shaped; the third, vestigial. The carena of the anterolateral margin of the carapace is inconspicuous between the external orbital angle and the first notch. The front and posterolateral margins of the carapace are finely granulated. The upper orbital margin is smooth. The smaller male $(\mathrm{CLxCW}=22 \times 24.9 \mathrm{~mm})$ is similar to the larger male, except that the anterolateral margin of the carapace is entirely carinate, and granules are seen between the external orbital angle and the first notch. The 2 females $(12.4 \times 14$ and 13.9x14.6 mm CLxCW) are very similar. The front is slightly granulated. The carapace is densely punctuated, the gastric elevations are prominent, and the carapace regions are well marked. The lateral margin of the carapace is entirely granulated. Three spines are present on the anterolateral margin. The first and second notches are conspicuous, the third, vestigial.

Characterization of form B (Figs. 7C, D): The frontal margin is carinate. Granules, if present, are inconspicuous. The exorbital angle is obtuse, unarmed in most cases, but an obsolete granule may be present. The lateral margin of the orbit is generally bordered with a series of small, closely spaced, similar-sized teeth, while the lower margin of the orbit is usually unarmed, sometimes provided with vestigial denticles. The upper margin is generally smooth.

The lateral margin of the carapace is smooth to carinate, and the opposed anterolateral margins are usually symmetrical. The anterolateral margin is provided with 1-3 notches and 0-2 small spines. The posterolateral margin is smooth or bordered by a tiny carena, but it sometimes has very fine granulation. The carapace is smooth, poorly punctuated, except near the frontal margin, with a more convex surface. Gastric elevations are, in many cases, not pronounced.

The chelipeds are generally smooth, weakly punctuated. The lines of denticles and granules found on the ventral surface of the merus of form A are absent or have a few teeth. An acute denticle may be present.

The male abdomen and gonopod characters agree well with the diagnosis provided by Magalhães (2003).

Three males of lot MZUESC\#956 (24.9$32 \times 32.5-36.3 \mathrm{~mm}$ CLxCW), from the Santana River basin, Ilhéus, are typical of form B (Figs. $7 \mathrm{C}, \mathrm{D})$. The carapace of these specimens is quite smooth. The front is carinate, but completely smooth. The exorbital angle is clearly unarmed. The anterolateral region is not bordered by a carena, but it contains 3 notches, the third one vestigial. The few teeth present around the lateral margin of the orbit are small and closely spaced. The process on the inner orbital angle of the orbit is rhombic. The ventral face of the merus of chelipeds is armed with a single tooth. The spine on the mid-dorsal distal region of the merus is reduced or absent.

The female of lot MZUESC\#513 (CLxCW $=18.8 \times 19.9 \mathrm{~mm}$ ), from Una, also has characteristics according to form $\mathrm{B}$. The lateral margin of the carapace is entirely carinate, with small sparse granules. Only 1 shallow notch is present on the anterolateral margin. The frontal margin and the upper orbital margin 
are smooth. The condition found in the male of lot MZUSP\#9698 (CLxCW = 21.6x23.6 mm), from Buerarema, is very similar, the frontal margin is slightly granulated and only one vestigial notch is present on the anterolateral margin of the carapace. No spines or granules are present on the ventral surface of the merus and ischium of the chelipeds.

Other typical individuals of form B are those from lot MZUSP\#10784, from Ceplac, Ilhéus. Both male $(\mathrm{CLxCW}=29.5 \times 35 \mathrm{~mm})$ and female $(\mathrm{CLxCW}=25.4 \times 28.6 \mathrm{~mm})$ have the lateral margin of the carapace entirely carinate, without granulation, and neither spines nor notches are present. The frontal margin is smooth, whereas the lateral and inferior margins of the orbits have some granulation. The ventral surfaces of the merus and ischium of the chelipeds are also smooth. Also from the same collection site and with identical characteristics are the male $(\mathrm{CLxCW}=29.1 \times 32.8$ $\mathrm{mm})$ and the female $(\mathrm{CLxCW}=22.5 \times 26.3$ $\mathrm{mm})$ of lot USU\#1515.

Outside the study area, all specimens are according to form $\mathrm{B}$, e.g., $1 \mathrm{~m}(\mathrm{CLxCW}=$ $30.5 \times 33.8 \mathrm{~mm})$ and $1 \mathrm{f}(\mathrm{CLxCW}=26 \times 27.8 \mathrm{~mm})$ from Rio Largo, Alagoas (DOUFPE\#13560); $1 \mathrm{~m}(\mathrm{CLxCW}=28.3 \times 30.5 \mathrm{~mm})$ from Amaraji River, Pernambuco (DOUFPE\#8731); $1 \mathrm{~m}$ $(\mathrm{CLxCW}=31.5 \times 36.7 \mathrm{~mm})$ from Maracás, Bahia (USU\#1511); 2f (23.9x26.4 and 20.8x22.1 mm CLxCW) from Wenceslau Guimarães, Bahia (MZUESC\#191), 4m $(\mathrm{CLxCW}=25-30.8 \times 28.5-34.7 \mathrm{~mm})$ from Santa Tereza, Espírito Santo (MZUSP\#1749); 2m (23.8x25.6 and $21.4 \times 23.8 \mathrm{~mm} \mathrm{CLxCW})$ and 1f $(\mathrm{CLxCW}=24.6 \times 27.5 \mathrm{~mm})$, also from Santa Tereza (MZUSP\#6374); and 2m (22.2x25.4 and $22.1 \times 25 \mathrm{~mm} \mathrm{CLxCW})$ and $1 \mathrm{f}(\mathrm{CLxCW}=$ 17.9x19.6 mm) from Conceição de Ibitipoca, Minas Gerais (USU\#1535).

A certain group of analyzed specimens, although more related to form A, do not reach the extreme degree of dentition found, for example, in the specimens of lot MZUESC\#452. Because the condition shown by them, in most cases, is also distant from form B, these specimens were considered as "intermediate" forms. The existence of several degrees of intermediate conditions in T. fluviatilis was previously reported by Magalhães (1991). Part of lot MZUESC\#956 (Santana River basin) seems to show the intermediate condition. One male $(\mathrm{CLxCW}=24.1 \times 27 \mathrm{~mm})$ and $2 \mathrm{f}(28 \times 31.6$ and $26.9 \times 31.6 \mathrm{~mm} \mathrm{CLxCW})$ are closely related to form $\mathrm{A}$, whereas $1 \mathrm{~m}(\mathrm{CLxCW}=29.7 \times 34.3$ $\mathrm{mm}$ ) is more closely related to form B. The specimens that resemble form A have 2 strong spines directed forward, and 2 notches on the anterolateral margin of carapace. However, the granulation on orbits, on posterolateral and frontal margin is weaker than that found in lots MZUESC\#452 and in two specimens of lot \#956 (as commented above). The individual that resembles form B has 1 reduced spine and 3 notches on the anterolateral margin of the carapace. The other margins (front, orbits, and posterolateral) are inconspicuously granulated.

The material from the district of Castelo Novo, Ilhéus (probably from the Almada River basin), $3 \mathrm{~m}$ (CLxCW $=10.7-19.7 \times 12.2-21.8$ $\mathrm{mm})$ and $6 \mathrm{f}(\mathrm{CLxCW}=8.6-27.8 \times 8.9-31.1$ $\mathrm{mm}$ ) (USU\#1568), was also considered intermediate. In this lot, individuals are usually provided with 2 spines and 2 shallow notches (sometimes the second notch is vestigial). A third notch, vestigial, is present in some specimens. The granulation on the frontal and posterolateral margins of the carapace is fine. The portion of the lateral margin situated between the external orbital angle and the first notch is finely granulated to smooth. The orbital margin is also ornate with granules. The spines and notches on the lateral anterolateral margin of the carapace are easily observed, even in the smallest specimen of this lot (female, CLxCW $=8.6 \times 8.9 \mathrm{~mm}$ ).

The condition found in the specimens of lot USU\#1533, 2 males $(16.2 \times 18.8$ and $11.3 \times 12.8$ $\mathrm{mm} \mathrm{CLxCW})$ and 4 females $(\mathrm{CLxCW}=6.5$ $13.1 \times 7.3 \times 15 \mathrm{~mm})$ is quite similar to those described above. The larger male $(\mathrm{CLxCW}=$ $16.2 \times 18.8 \mathrm{~mm}$ ) has the anterolateral margin of carapace with 3 notches, the third vestigial. The first notch is succeeded by an acute spine, whereas the second by an obsolete spine. In the 
smaller specimens, the third, and sometimes the second notch, are vestigial.

Other specimens difficult to attribute to either of the two forms are those from Chapada Diamantina, central Bahia. Although from outside the study area, characteristics of this material should be mentioned. In general appearance the specimens are morphologically similar (lots USU\#1519, \#1522, \#1527, \#1528, \#1529, \#1531, \#1532, \#1536). All material mentioned above was labeled Trichodactylus cf. fluviatilis by Dr. Célio Magalhães. There is a resemblance between the specimens from Chapada Diamantina and those from lots MZUESC\#956 and USU\#1533. The carapace is punctuated and hairy. The frontal margin is, in general, smooth. The orbit is slightly granulated. The lateral margin of the carapace, entirely carinate, is generally provided with 1 small spine (rarely 2) and 3 notches (sometimes 2). Some individuals have slight granulation on the posterolateral margin of the carapace. The distal dorsal spine on the merus of the chelipeds, usually conspicuous in the examined material, is reduced or absent in the present specimens.

The spinulated form A seems not to be related to size/age or sex. Also both forms occur, in some cases, at the same site (e.g., Santana River basin). Magalhães (1991) also observed significant variability in specimens from the same basin or region, or even within the same lot. Form A was restricted, in the material examined by us, to southeast Bahia, more precisely to the Cachoeira River basin (which includes the Santana River). Part of the material from the Almada River and Santana River basins, and that from Chapada Diamantina was considered as an intermediate state between the two forms. The material from northern and southern Bahia, and from other states (Pernambuco, Alagoas, Espírito Santo, and Minas Gerais), is according to form B. As pointed out by Magalhães (1991), only the examination of material from the entire geographical range of $T$. fluviatilis, plus studies involving molecular analysis, could clarify whether T. fluviatilis is a single, morphologically highly variable species, or whether it represents a complex of related species. It is also important to collect in other sites of the Cachoeira River basin and surrounding basins in order to obtain more accurate data with respect to the range of form $\mathrm{A}$.

Fisheries: No fishery interest. Sometimes used as food, but rarely.

\section{Superfamily Xanthoidea MacLeay, 1838 \\ Family Panopeidae Ortmann, 1893 Panopeus rugosus \\ A. Milne-Edwards, 1881 (Fig. 9)}

References: Brazil - A. Milne-Edwards (1881); Moreira (1901); Rathbun (1930); Coelho and Ramos (1972); Coelho Filho and Coelho (1996); Melo (1996, 1998, 1999), Calado and Sousa (2003). State of Bahia A. Milne-Edwards (1881); Moreira (1901); Rathbun (1930), Cannavieiras (= Canavieiras), Thayer Expedition; Melo (1985), Ilhéus; Almeida et al. (2006), Ilhéus, estuaries of Acuípe, Almada, and Cachoeira rivers, and Parque Municipal da Boa Esperança; Almeida et al. (2007), Camamu Bay.

Material: 1m, 1f,30.IV.2004, SantanaRiver, Povoado Rio do Engenho, Ilhéus (1451'07.4”S; 3904'12.8”W) (MZUESC\#367).

Distribution: Western Atlantic - United States (Florida), Gulf of Mexico, Central America, Antilles, northern South America, Guyanas, and Brazil (from Pernambuco to Rio Grande do Sul) (Melo 1996).

Ecological notes: Estuarine species living on mud, among mangrove roots (Calado and Sousa 2003). Powers (1977) and Melo (1996, 1998) noted its occurrence on sand, shells, rocks, and coral bottoms.

Remarks: The type locality of $P$. rugosus is "Bahia" (A. Milne-Edwards 1881). This mud crab has a wide latitudinal range in the western Atlantic, from Florida to southern Brazil, and the Antilles (Melo 1996). As C. bocourti, this crab belongs to the group of Antillean Continuous species (Melo 1985). Although this crab is typically estuarine, our specimens were collected in fresh water, in a riffle area in the Santana River near the Rio do Engenho 


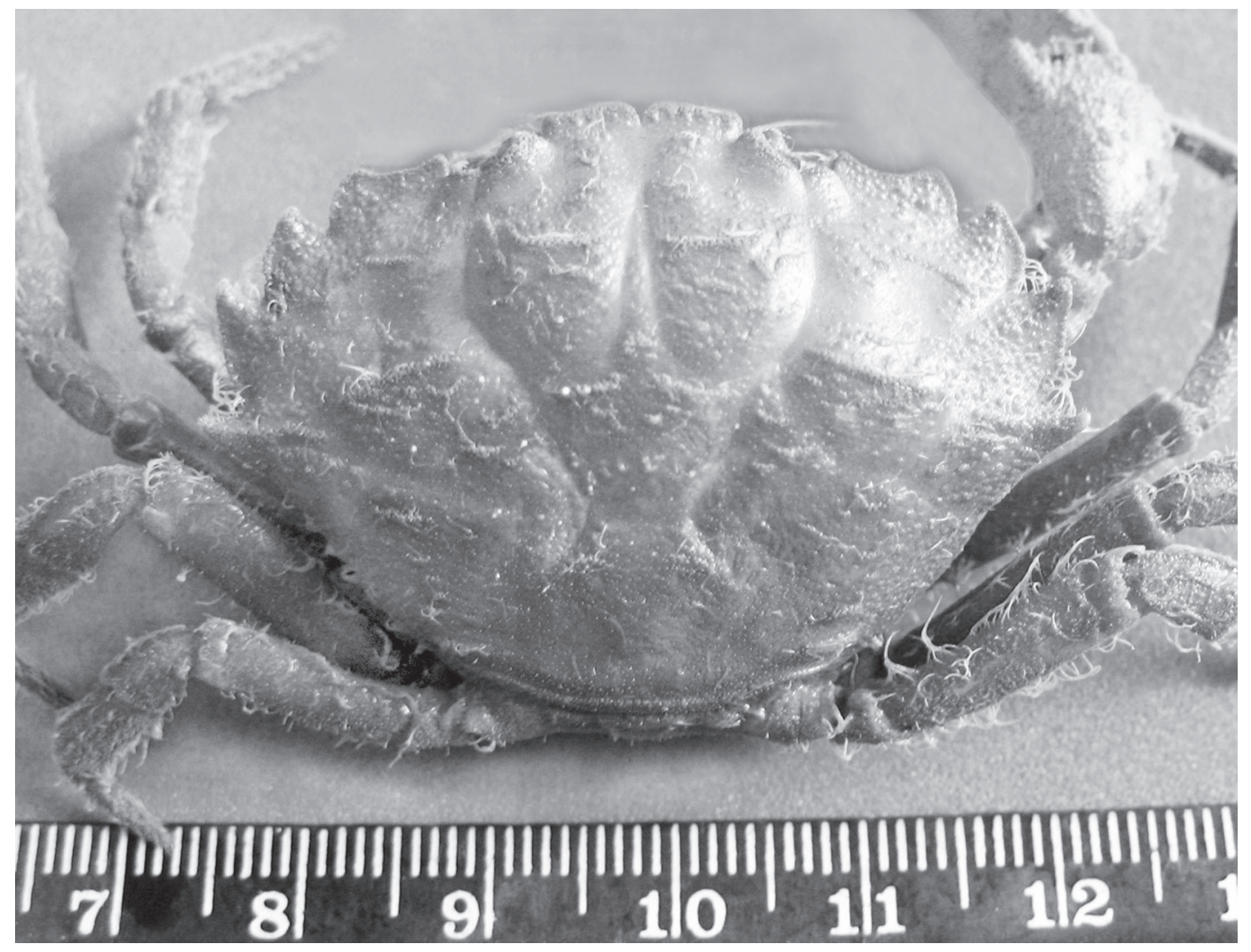

Fig. 9. Panopeus rugosus A. Milne-Edwards, from the Almada River, Ilhéus, Bahia, Brazil, male (MZUESC\#561), dorsal view of carapace.

reservoir (this area is close to the upper tidal limit of the river). This uncommon record of $P$. rugosus in fresh water indicates high tolerance to salinity changes, and perhaps a preference for low-salinity water. Calado and Sousa (2003), studying the estuarine crustaceans from Mundaú and Manguaba lagoons, Alagoas, found this species in water of salinities from 1.2 to 5.3. Previous records for Bahia came from estuarine waters (Melo 1985, Almeida et al. 2006, 2007).

This species can be differentiated from all other crabs found in fresh water in the study area by the presence of 5 teeth on the anterolateral margin. The carapace and chelipeds are remarkably rough (Coelho Filho and Coelho 1996, Melo 1996), contrasting with other species of Panopeus H. Milne-Edwards, 1834 reported from Brazilian waters. The palm of chelipeds has 3 longitudinal raised lines on its outer surface. The fingers are deeply grooved (Rathbun 1930, Melo 1996). A conspicuous groove is present in the distal region of the carpus of the chelipeds (Coelho Filho and Coelho 1996). The carapace surface is pubescent, intermingled with longer setae. The frontal region of the carapace is divided by a V-shaped sinus (Rathbun 1930, Melo 1996). 


\section{Preliminary key for identification of freshwater carideans from the study area (adapted from Holthuis 1952, Chace 1972, Melo 2003)}

(1) First and second pereiopods with fingers usually bearing conspicuous terminal brushes .... of long hairs $\ldots \ldots \ldots \ldots \ldots \ldots \ldots \ldots \ldots \ldots \ldots \ldots \ldots \ldots \ldots \ldots \ldots \ldots \ldots \ldots$ (family Atyidae)

(1') First and second pereiopods with fingers not bearing terminal brushes of long hairs .......

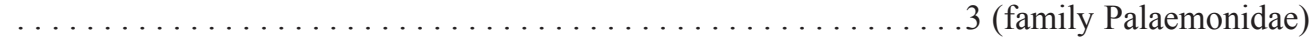

(2) Carpus of pereiopod 2 short, broader than long; anterior part of the same deeply excavated ..

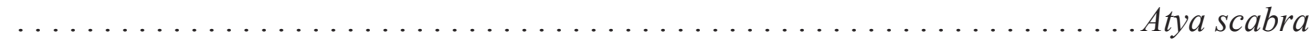

(2') Carpus of pereiopod 2 longer than broad; anterior part of the same generally not deeply exca-

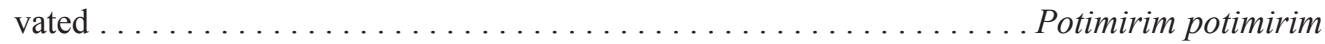

(3) Hepatic spine absent; branchiostegal spine present $\ldots \ldots \ldots \ldots$. . . . . Paemon pandaliformis

(3') Hepatic spine present; branchiostegal spine absent $\ldots \ldots \ldots \ldots \ldots \ldots \ldots \ldots \ldots$

(4) Telson gradually tapering towards posterior margin, ending in a sharp median point, not overreached by the two pairs of spines located on the posterior margin $\ldots \ldots \ldots \ldots \ldots \ldots \ldots$

(4') Telson with a distinct posterior margin; the inner pair of posterior spines generally overreaches

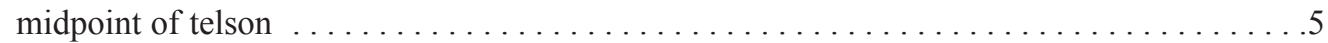

(5) Carpus of chelipeds distinctly shorter than merus .......... Macrobrachium carcinus

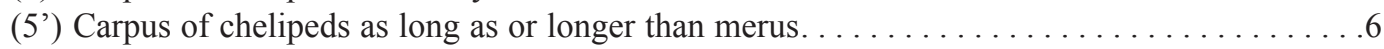

(6) Chelipeds strongly unequal in shape and size; cutting edge with teeth regularly distributed...

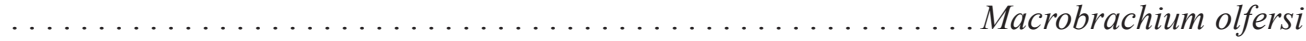

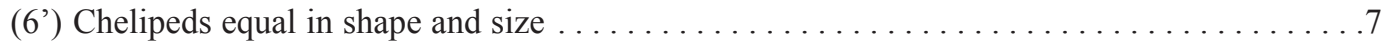

(7) Inner posterior spines of telson short, not overreaching posterior margin of telson ........

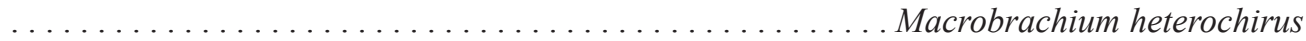

(7') Inner posterior spines of telson long, overreaching posterior margin of telson $\ldots \ldots \ldots .8$

(8) Rostrum with 9-11 teeth on dorsal margin; fingers of chelipeds covered by dense velvety pubescence; merus, carpus, and palm with spines; small eggs . . Macrobrachium acanthurus

(8') Rostrum with 6-7 (rarely 5-8) teeth on dorsal margin; fingers of chelipeds not covered by dense velvety pubescence; chelipeds tiny, merus, carpus, and palm smooth; larger eggs . . . . . . .

Macrobrachium jelskii

\section{DISCUSSION}

The 13 freshwater species previously reported from the state of Bahia are the following: Atya scabra, Potimirim potimirim, $M$. acanthurus, M. amazonicum, M. brasiliense (Heller, 1862), M. carcinus, M. denticulatum, M. jelskii, M. nattereri (Heller, 1862), M. olfersi (Wiegmann, 1836), Palaemon (Palaemon) pandaliformis, Goyazana castelnaui $\mathrm{H}$. MilneEdwards, 1853, and Trichodactylus fluviatilis (Ramos-Porto and Coelho 1998, Magalhães 2003, Melo 2003).
The record of $M$. nattereri (Gomes Correa 1977) is based on a misidentification (P. A. Coelho, personal observation). This species seems to be restricted, in Brazil, to the Amazon region, and should be removed from the list of freshwater decapods from Bahia.

To this list should be added M. heterochirus, reported herein for the first time, and Callinectes bocourti and C. sapidus, of which adults are frequently found in freshwater. The record of the estuarine mud crab Panopeus rugosus is probably accidental, but shows that this species prefers low-salinity environments, 
as also observed by Calado and Souza (2003) in Alagoas.

The only species distributed in drainages of both sides of the Atlantic is A. scabra (Hobbs and Hart 1982, Ramos-Porto and Coelho 1998, Melo 2003). Trichodactylus fluviatilis is the only species collected that is endemic to Brazil. Among the species that have been reported from Bahia, M. denticulatum is restricted, to the present date, to the São Francisco River basin (Ostrovski et al. 1996, Ramos-Porto and Coelho 1998, Melo 2003). Macrobrachium birai and $M$. holthuisi are species that, given their presently known range, potentially occur in Bahia.

The number of species reported from Bahia can be considered low. In the state of São Paulo, for example, which has a smaller territory, 32 freshwater decapod species are reported (Magalhães 2003). The number of species from the state of Bahia is certainly much larger, and should increase with the accomplishment of more comprehensive and systematic collections, especially in the central, southeastern, and southern coastal regions covered by Atlantic Forest, to the west of the São Francisco River, and in the headwaters of the Chapada Diamantina. This state contains the largest remnants of the Atlantic Forest in northeastern Brazil (Faria et al. 2006), with some areas situated at altitudes around $900 \mathrm{~m}$, that have a high potential for the discovery of new species.

\section{ACKNOWLEDGMENTS}

To UESC for financing the project "Inventariamento da fauna de crustáceos decápodos do município de Ilhéus, Bahia" (00220.1100.337). To Célio Magalhães (INPA) for his usual attention and criticisms of the manuscript. To Marcos Tavares and Gustavo Melo for permitting examination of material deposited in the MZUSP and USU collections. To Janet Reid for assistance with the English text. To Aldaléa S. Tavares (UFSC), for the identification of Mourera sp. To Arthur Anker, Vilson Câmara, Rui R. Cavalcanti, Cynthia
Soares, Ana Cácia F. Santos, Binael S. Santos (in memoriam), Luis Alberto Mattos, and César Almeida for their help at several times during the course of this research. A.O. Almeida and P.A. Coelho thank, respectively, FAPESB (Fundação de Amparo à Pesquisa do Estado da Bahia) and CNPq for research productivity scholarships. Undergraduate students J.T.A. Santos and J.R. Luz were supported by a FAPESB scholarship, and N.R. Ferraz was granted scholarships by $\mathrm{CNPq}$ and PROIIC/ UESC.

\section{RESUMEN}

Se conoce un total de 117 especies de crustáceos decápodos de agua dulce en Brasil. El conocimiento de la fauna de decápodos de las aguas continentales en el estado de Bahia, noreste de Brasil, es incipiente. A pesar de su amplio territorio y una rica red hidrográfica, solo se conoce de 13 especies de decápodos limnéticos en ese estado. El objetivo de este proyecto fue estudiar los crustáceos decápodos de algunas cuencas hidrográficas en el sureste de Bahia. El material descrito aquí se obtuvo de muestreos llevados a cabo entre 1997 y 2005. Los especímenes testigo se depositaron en las colecciones carcinológicas del Museo de Zoología, Universidade Estadual de Santa Cruz, Ilhéus, Brasil, y en el departamento de Oceanografía, Universidade Estadual de Santa Cruz, Ilhéus, Brasil. Se recolectó un total de 13 especies. Los carideos estuvieron representados por los átidos Atya scabra (Leach, 1815) y Potimirim potimirim (Müller, 1881) y los palaemónidos Macrobrachium acanthurus (Wiegmann, 1836), M. amazonicum (Heller, 1862), M. carcinus (Linnaeus, 1758), M. heterochirus (Wiegmann, 1836), M. jelskii (Miers, 1877), M. olfersi (Wiegmann, 1836), y Palaemon (Palaemon) pandaliformis (Stimpson, 1871). Los braquiuros estuvieron representados por los portúnidos Callinectes bocourti A. Milne-Edwards, 1879 y C. sapidus Rathbun, 1895, los tricodáctilos Trichodactylus fluviatilis Latreille, 1828 y el panopeido Panopeus rugosus A. Milne-Edwards, 1881. Macrobrachium heterochirus representa un nuevo registro en Bahia, y M. amazonicum se halló por primera vez en el sureste de Bahia. Se observó la existencia de dos formas diferentes extremas de T. fluviatilis. La forma A se caracteriza por el margen frontal del caparazón bordeado por gránulos conspicuos, el margen anterolateral presenta dientes desarrollados además de gránulos, y el margen posterolateral presenta granulación similar a la encontrada en el frontal. En la forma B el margen frontal es liso o tiene granulación incospicua; el margen anterolateral presenta usualmente 1-3 muescas, y los dientes, si están presentes (1-2), son pequeños; y el margen posterolateral es liso o levemente granulado. 
Palabras clave: camarones de agua dulce, Caridea, Callinectes, Trichodactylus, Panopeus, Brachyura, fauna brasileña.

\section{REFERENCES}

Abele, L.G. 1971. Introductions of two freshwater decapod crustaceans (Hymenosomatidae and Atyidae) into Central and North America. Crustaceana 23: 209-218.

Almeida, A.O., P.A. Coelho, J.T.A. Santos \& N.R. Ferraz. 2006. Crustáceos decápodos estuarinos de Ilhéus, Bahia, Brasil. Biota Neotrop. 6(2): http:/www.biotaneotropica.org.br/v6n2/pt/abstract?inventory+bn03 406022006

Almeida, A.O., M.C. Guerrazzi \& P.A. Coelho. 2007. Stomatopod and decapod crustaceans from Camamu Bay, state of Bahia, Brazil. Zootaxa 1553: 1-45.

Amaral, A.C.Z. 2005. Invertebrados aquáticos, p. 99-118. In A.B.M. Machado, C.S. Martins, G.M. Drummond (orgs.). Lista da fauna Brasileira ameaçada de extinção: incluindo espécies quase ameaçadas e deficientes em dados. Fundação, Biodiversitas, Belo Horizonte, Minas Gerais, Brazil.

Argôlo, A.J.S. 2004. As serpentes dos cacauais do sudeste da Bahia. Editus, Ilhéus, Bahia, Brasil. 260 p.

Arraes, R.R. \& M. Ramos-Porto. 1994. Contribuição ao estudo das águas interiores do Nordeste do Brasil (Crustacea, Decapoda). Rev. Nord. Zool. 1: 61-88.

Barros, M.P. \& A.S. Braun. 1997. Contribuição ao estudo dos Atyidae e Palaemonidae (Crustacea, Decapoda) do leste brasileiro $14^{\circ} 21^{\prime}$ e $20^{\circ} 55^{\prime}$ de latitude sul. Biotemas 10: 7-26.

Bond-Buckup, G. 2003. Família Aeglidae, p. 21-116. In G.A.S. Melo (org.). Manual de Identificação dos Crustacea Decapoda de Água Doce do Brasil. Edições Loyola, São Paulo, SP, Brazil.

Bond-Buckup, G \& L. Buckup. 1989. Os Palaemonidae de águas continentais do Brasil meridional (Crustacea, Decapoda). Rev. Bras. Biol. 49: 883-896.

Bond-Buckup, G. \& L. Buckup. 1994. A família Aeglidae (Crustacea, Decapoda, Anomura). Arq. Zool. 32: 159-346.

Bond-Buckup, G. \& L. Buckup. 1999. Caridea (pitus, camarões de água doce e marinhos), p. 300-318. In G. Bond-Buckup \& L. Buckup (eds.). Os Crustáceos do Rio Grande do Sul. Editora da Universidade/UFRGS, Porto Alegre, Rio Grande do Sul, Brazil.
Bott, R. 1969. Die Süsswasserkrabben Süd-Amerikas und ihre Stammesgeschichte. Abh. senckenberg. Naturforsch. Ges. 518: 1-94.

Bowles, D.E., K. Aziz \& C.L. Knight. 2000. Macrobrachium (Decapoda: Caridea: Palaemonidae) in the contiguous United States: A review of the species and an assessment of threats to their survival. J. Crust. Biol. 20: $158-171$.

Buckup, L. 2003. Família Parastacidae, p. 117-141. In G.A.S. Melo (org.). Manual de Identificação dos Crustacea Decapoda de Água Doce do Brasil. Edições Loyola, São Paulo, SP, Brazil.

Calado, T.C.S. 2000. Registro de Callinectes sapidus Rathbun, 1896 (Crustacea Decapoda, Portunidae) na confluência dos rios Traipu e São Francisco (TraipuAlagoas). Bol. Estud. Ciênc. Mar 11: 113-117.

Calado, T.C.S. \& E.C. Sousa. 2003. Crustáceos do complexo estuarino-lagunar Mundaú/Manguaba Alagoas. FAPEAL, Maceió, Alagoas, Brazil. 116 p.

Chace, F.A., Jr. 1972. The shrimps of the SmithsonianBredin Caribbean Expeditions with a summary of the West Indian shallow-water species (Crustacea: Decapoda: Natantia). Smithson. Contr. Zool. 98: 1-179.

Chace, F.A., Jr. \& H.H. Hobbs Jr. 1969. The Freshwater and Terrestrial Decapod Crustaceans of the West Indies with Special Reference to Dominica. U. S. Nat. Mus. Bull. 292: 1-256.

Coelho, P.A. 1963. Observações preliminares sobre a biologia e a pesca dos camarões do gênero Macrobrachium Bate, 1868 (Decapoda Palaemonidae) no Estado de Pernambuco, Brasil. Trabs. I. O. Univ. Recife 3: 75-81.

Coelho, P.A. \& M.A. Ramos. 1972. A constituição e a distribuição da fauna de decápodos do litoral leste da América do Sul entre as latitudes $5^{\circ} \mathrm{N}$ e $39^{\circ} \mathrm{S}$. Trab. Oceanogr. Univ. Fed. Pe. 13: 133-236.

Coelho, P.A. \& M. Ramos-Porto. 1992. Sinopse dos crustáceos decápodos brasileiros (Portunidae). Revta bras. Zool. 9: 291-298.

Coelho Filho, P.A. \& P.A. Coelho. 1996. Sinopse dos crustáceos decápodos brasileiros (família Xanthidae). Trab. Oceanogr. Univ. Fed. Pe. 24: 179-195.

Collins, P. 2000. A new distribution record for Macrobrachium jelskii (Miers, 1877) in Argentina (Decapoda, Palaemonidae). Crustaceana 73: 11671169. 
Faria, D., B. Soares-Santos \& E. Sampaio. 2006. Bats from the Atlantic rainforest from southern Bahia, Brazil. Biota Neotrop. 6 (2): http://www.biotaneotropica.org. br/v6n2/pt/abstract?inventory+bn02406022006

Gamba, A. 1982. Macrobrachium: its presence in estuaries of the northern Vevezuelan coast (Decapoda, Palaemonidae). Carib. J. Sci. 18: 23-25, figs.1-4: 135-136.

Garbe, E. 1920. Relatório da viagem ao Sul do Estado da Bahia. Rev. Mus. Paulista, 12: 469-478.

García-Dávila, C.R. \& C. Magalhães. 2003. Revisão taxonômica dos camarões de água doce (Crustacea: Decapoda: Palaemonidae, Sergestidae) da Amazônia Peruana. Acta Amazonica 33: 663-686.

Genofre, G.C. \& V.L. Lobão. 1978. Macrobrachium holthuisi sp. n. a new species of shrimp (Decapoda, Macrura). Crustaceana 35: 273-276.

Göldi, E.A. 1885. Studien über neue und wenig bekannte Podophthalmen Brasiliens. Vorläufige Notiz. Zool. Anz. 8: 662-663.

Göldi, E.A. 1886. Studien über neue und weniger bekannte Podophthalmen Brasiliens. Arch. Naturgesch. 52: $19-46$.

Gomes Corrêa, M.M. 1977. Palemonídeos do Brasil (Crustacea - Decapoda - Natantia). Master Thesis, Rio de Janeiro, Brazil. 135 p.

Hart, C.W., Jr. 1961. The Freshwater Shrimps (Atyidae and Palaemonidae) of Jamaica, W.I., With a Discussion of Their Relation to the Ancient Geography of the Western Caribbean Area. Proc. Acad. Nat. Sci., Phila. 113: 61-80.

Hobbs, H.H., Jr. \& C.W. Hart Jr. 1982. The Shrimp Genus Atya (Decapoda: Atyidae). Smithson. Contrib. Zool. 364: 1-143.

Holthuis, L.B. 1952. A general revision of the Palaemonidae (Crustacea Decapoda Natantia) of the Americas. II. The subfamily Palaemoninae. Allan Hancock Foundation Occasional Papers 12: 1-396.

Holthuis, L.B. 1966. A collection of freshwater prawns (Crustacea Decapoda, Palaemonidae) from Amazonia, Brazil, collected by Dr. G. Marlier. Bull. Inst. Roy. Sci. Nat. Belg. 41: 1-11.

Holthuis, L.B. 1980. Shrimps and prawns of the world. An annotated catalogue of species of interest to fisheries. FAO Fish. Syn. 125: 1-271.
Holthuis, L.B. 1986. Fresh-water shrimps of the Family Atyidae from Western Colombia. J. Crust. Biol. 6: 438-445.

Holthuis, L.B. \& A.J. Provenzano Jr. 1970. New distribution records for species of Macrobrachium with notes on the distribution of the genus in Florida (Decapoda, Palaemonidae). Crustaceana 19: 211-213.

Ihering, H. von. 1897. Os camarões da agua doce do Brazil. Rev. Mus. Paulista 2: 421-432.

Kensley, B. \& I. Walker. 1982. Palaemonid Shrimps from the Amazon Basin, Brazil (Crustacea: Decapoda: Natantia). Smithson. Contr. Zool. 362: 1-28.

Magalhães, C. 1991. Revisão taxonômica dos caranguejos dulcícolas da família Trichodactylidae (Crustacea: Decapoda, Brachyura). PhD Thesis, São Paulo, Brazil. 175 p.

Magalhães, C. 1998. Malacostraca. Eucarida. Brachyura: Pseudothelphusidae and Trichodactylidae, p. 517523. In P.S. Young (ed.). Catalogue of Crustacea of Brazil. Museu Nacional, Rio de Janeiro, RJ, Brazil.

Magalhães, C. 1999. Crustáceos Decápodos, p. 127-133. In D. Ismael, W.C. Valenti, T. Matsumura-Tundisi \& O. Rocha (orgs.). Biodiversidade do Estado de São Paulo, Brasil: síntese do conhecimento ao final do século XX. Invertebrados de Água Doce. Vol. 4. FAPESP, São Paulo, SP, Brazil.

Magalhães, C. 2000. Caracterização da comunidade de crustáceos decápodos do Pantanal, Mato Grosso do Sul, Brasil. In B. Chernoff, L.E. Alonso, J.R. Montambault \& R. Lourival (eds.). A biological assessment of the aquatic ecosystems of the Pantanal, Mato Grosso do Sul, Brazil (Conservation International, Washington, RAP Bulletin of Biological Assessment, 18, pp. 175182, appendix 5, pp. 287-290).

Magalhães, C. 2003. Famílias Pseudothelphusidae e Trichodactylidae, p. 143-287. In G.A.S. Melo (org.) Manual de Identificação dos Crustacea Decapoda de Água Doce do Brasil. Edições Loyola, São Paulo, SP, Brazil.

Magalhães, C., S.L.S. Bueno, G. Bond-Buckup, W.C. Valenti, H.L. Melo da Silva, F. Kiyohara, E.C. Mossolin \& S.S. Rocha. 2005. Exotic species of freshwater decapod crustaceans in the state of São Paulo, Brazil: records and possible causes of their introduction. Biodiv. Cons. 14: 1929-1945.

Magalhães, C. \& M. Türkay. 1996. Taxonomy of the neotropical freshwater crab family Trichodactylidae. I. The generic system with description of some new genera (Crustacea: Decapoda: Brachyura). Senckenberg. biol. 75: 63-95. 
Martin, J.W. \& G.E. Davis. 2001. An Updated Classification of the Recent Crustacea. Natural History Museum of Los Angeles County, Science Series, 39: 1-124.

Mejía-Ortiz, L.M., F. Alvarez, R. Román \& J.A. VicconPale. 2001. Fecundity and distribution of freshwater prawns of the genus Macrobrachium in Huitzilapan River, Veracruz, Mexico. Crustaceana 74: 69-77.

Melo, G.A.S. 1967. Diferenciação geográfica e dimorfismo sexual de Trichodactylus (Trichodactylus) fluviatilis Latreille, 1825 (Crustacea, Brachyura). Papéis Avulsos Zool. 20: 13-44.

Melo, G.A.S. 1985. Taxonomia e padrões distribucionais e ecológicos dos Brachyura (Crustacea, Decapoda) do litoral sudeste do Brasil. PhD Thesis, São Paulo, Brazil. 215 p.

Melo, G.A.S. 1996. Manual de identificação dos Brachyura (caranguejos e siris) do litoral brasileiro. Editora Plêiade, São Paulo, SP, Brazil. 603 p.

Melo, G.A.S. 1998. Malacostraca. Eucarida. Brachyura: Oxyrhyncha and Brachyrhyncha, p. 455-515. In P.S. Young (ed.). Catalogue of Crustacea of Brazil. Museu Nacional, Rio de Janeiro, RJ, Brazil.

Melo, G.A.S. 1999. Infraordem Brachyura (Siris e caranguejos: espécies marinhas e estuarinas), p. 415-485. In G. Bond-Buckup \& L Buckup (eds.). Os Crustáceos do Rio Grande do Sul. Editora da Universidade/UFRGS, Porto Alegre, Rio Grande do Sul, Brazil

Melo, G.A.S. 2003. Famílias Atyidae, Palaemonidae e Sergestidae, p. 289-415. In G.A.S. Melo (ed.). Manual de identificação dos Crustacea Decapoda de água doce do Brasil. Edições Loyola, São Paulo, SP, Brazil.

Melo, G.A.S., V.L. Lobão \& W.M. Fernandes. 1988. Redescrição de Macrobrachium birai Lobão, Melo \& Fernandes e de Macrobrachium petronioi Melo, Lobão \& Fernandes (Crustacea: Decapoda), palemonídeos da região sul do Estado de São Paulo. B. Inst. Pesca. 15: 89-97.

Melo, G.A.S., V.G. Veloso \& M.C. Oliveira. 1989. A fauna de Brachyura (Crustacea, Decapoda) do litoral do Estado do Paraná. Lista preliminar. Nerítica 4: 1-31.

Milne-Edwards, A. 1869. Révision des genres Trichodactylus, Sylviocarcinus et Dilocarcinus et description de qualques espèces nouvelles qui s'y rattachent. Annls. Soc. entom. France 9: 170-178.

Milne-Edwards, A. 1881. Études sur les Crustacés Podophthalmaires de la región mexicaine. Recherches Zoologiques pour Servir à l'Histoire de la Faune de l'Amérique Centrale et du Mexique 5: 313-368.
Moraes-Riodades, P.M.C., W.C. Valenti, A.S.L. Peralta \& M.D.L. Amorim. 1999. Carcinicultura de água doce no Estado do Pará: situação atual e perspectivas. Anais do XI CONBEP, Recife 2: 598-604.

Moreira, C. 1901. Contribuições para o conhecimento da fauna brasileira. Crustaceos do Brazil. Arch. Mus. Nac. 11: 1-151.

Müller, F. 1881. Atyoida potimirim, eine schlammfressende Susswassergarneele. Cosmos 9: 117-124.

Oliveira, L.P.H. 1945. Verificação da existência de Atya scabra Leach, camarão d'água doce da família Atyidae, Crustacea, no nordeste do Brasil. Mem. Inst. Oswaldo Cruz 43: 177-190.

Ortmann, A.E. 1891. Versuch einer Revision der Gattungen Palaemon sens. strict. und Bithynis. Die DecapodenKrebse des Strassburger Museums, mit besonderer Berkücksichtigung der von Herrn Dr. Döderlein bei Japan und bei den Liu-Kiu-Inseln gesammelten und z. Z. im Strassburger Museum aufbewahrten Formen. II. Theil. Zool. Jb. Syst. 5: 693-750.

Ortmann, A.E. 1897. Os camarões de agua doce da America do Sul. Rev. Mus. Paulista 2: 173-216.

Ostrovski, M.C., K.M.L. Fonseca \& T.C.G. Silva-Ferreira. 1996. Macrobrachium denticulatum sp. n. a new species of shrimp from the São Francisco basin, northeastern Brazil (Decapoda, Palaemonidae). Crustaceana 69: 359-367.

Paim, J.P., M.C. Peso-Aguiar, C.R.G. Carqueija, T.C.A. Almeida \& R.C.F. Assis. 1997. Ocorrência de Potimirim potimirim (Müller, 1881) (Crustacea, Decapoda, Atyidae) no rio Mucuri-Bahia. Nauplius 5: 147-148.

Powers, L.W. 1977. A catalogue and bibliography to the crabs (Brachyura) of the Gulf of Mexico. Contr. Mar. Sci. 20 (Suppl.): 1-190.

Ramos-Porto, M. \& P.A. Coelho. 1990. Sinopse dos crustáceos decápodos brasileiros (família Palaemonidae). An. Soc. Nordest. Zool. 3: 93-111.

Ramos-Porto, M. \& P.A. Coelho. 1998. Malacostraca. Eucarida. Caridea (Alpheoidea excluded), p. 325350. In P.S. Young (ed.). Catalogue of Crustacea of Brazil. Museu Nacional, Rio de Janeiro, RJ, Brazil.

Rathbun, M.J. 1896. The genus Callinectes. Proc. U. S. Nat. Mus. 18: 349-375.

Rathbun, M.J. 1906. Les crabes d'eau douce (Potamidae). Nouv. Arch. Mus. Hist. nat. Paris 8: 33-122. 
Rathbun, M.J. 1930. The cancroid crabs of America of the families Euryalidae, Portunidae, Atelecyclidae, Cancridae and Xanthidae. Bull. U. S. Nat. Mus. 152: 1-609.

Rocha, S.S. \& S.L.S. Bueno. 2004. Crustáceos decápodos de água doce com ocorrência no Vale do Ribeira de Iguape e rios costeiros adjacentes, São Paulo, Brasil. Revta. bras. Zool. 21: 1001-1010.

Rocha Filho, C.A. 1976. Recursos hídricos. Diagnótico Socioeconômico da Região Cacaueira. Vol. 5. Convênio IICA/Ceplac, Cartográfica Cruzeiro do Sul, Rio de Janeiro, RJ, Brazil. 133 p.

Rodríguez, G. 1992. The freshwater crabs of America. Family Trichodactylidae and Supplement to the Family Pseudothelphusidae. Collection Faune tropicale, XXXI. Editions de l'ORSTOM, Paris, France. 189 p.

Rodríguez, G. \& H. Suárez. 2001. Anthropogenic dispersal of decapod crustaceans in aquatic environments. Interciencia 26: 282-288.

Rodríguez-Almaraz, G.A. \& E. Campos. 1996. New locality records of freshwater decapods from México (Crustacea: Atyidae, Cambaridae, and Palaemonidae). Proc. Biol. Soc. Wash. 109: 34-38.

Roeder, M. 1975. Reconhecimento climatológico. Diagnóstico Socioeconômico da Região Cacaueira. Vol. 4. Convênio IICA/Ceplac, Cartográfica Cruzeiro do Sul, Rio de Janeiro, RJ, Brazil. 89 p.

Santos, C.R.M. \& F. D’Incao. 2004. Crustáceos no cerrito Ariano Souza, Rio Grande, Rio Grande do Sul e distribuição de Callinectes sapidus (Brachyura, Portunidae). Iheringia, Ser. Zool. 94: 73-76.

Santos, S., P.J. Rieger, R.R.R. Vieira \& R.A. Barutot. 2000. Composição e abundância dos Crustacea (Decapoda) na lagoa do Peixe, Rio Grande do Sul, Brasil. Revta bras. Zool. 17: 213-223.

Sawaya, M.P. 1946. Sôbre alguns camarões dágua doce do Brasil. Bol. Fac. Fil. Ciên. Letr. Univ. S. Paulo zool. 11: 393-408.
Semper, C. 1869. Some remarks on the Genus Macrobrachium of Mr. Spence Bate. Proc. Zool. Soc. Lond. 1868: 585-587.

Smalley, A.E. 1963. The genus Potimirim in Central America (Crustacea, Atyidae). Rev. Biol. Trop. 11: 177-183.

Smith, S.I. 1869. Notice of the Crustacea collected by Prof. C.F Hartt on the coast of Brazil in 1967. Trans. Conn. Acad. Arts Sci. 2: 1-41.

Taissoun, E. 1973. Los cangrejos de la família "Portunidae" (Crustaceos Decapodos Brachyura) en el Occidente de Venezuela. Bol. Centro Invest. Biol. 8: 1-77.

Tavares, M. \& J.B. Mendonça Jr. 2004. Introdução de Crustáceos Exóticos no Brasil: Uma Roleta Ecológica, p. 59-76. In J. Silva, R. Souza (eds.). Água de Lastro e Bioinvasão. Interciência, Rio de Janeiro, RJ, Brazil.

Villalobos, A. 1959. Contribucion al conocimiento de los Atyidae de México. II (Crustacea, Decapoda). Estudio de algunas espécies del gênero Potimirim (=Ortmannia), com descripción de uma especie nueva em Brasil. An. Inst. Biol. Mex. 30: 269330.

Villalobos, A. 1969. Problemas de especiación em America de um grupo de Palaemonidae del genero Macrobrachium. FAO Fish. Rep. 57: 1055-1066.

Vinha, S.G., T.J.S. Ramos \& M. Hori. 1976. Inventário Florestal. Diagnótico Socioeconômico da Região Cacaueira. Vol. 7. Convênio IICA/Ceplac, Cartográfica Cruzeiro do Sul, Rio de Janeiro, RJ, Brazil. 212 p.

White, A. 1847. List of the specimens of Crustacea in the Collection of the British Museum. London. 143 p.

Williams, A.B. 1974. The swimming crabs of the genus Callinectes (Decapoda, Portunidae). Fish. Bull. 72: 685-798. 